\title{
The Enigma of Hostile Takeovers in Japan: Bidder Beware
}

\author{
Dan W. Puchniak ${ }^{\dagger} \&$ Masafumi Nakahigashi ${ }^{\dagger+*}$
}

For over two decades, Japan has ostensibly had all of the essential elements that leading academics and sophisticated investors have assumed to be sufficient for a country to develop an active market for hostile takeovers (i.e., dispersed shareholder ownership, depressed share values, and a United Kingdom- or United States-inspired regulatory framework). This has not gone unnoticed. For decades, leading academics and prestigious pundits have repeatedly predicted the imminent arrival of a wave of successful hostile takeovers in Japan. Based on the same prediction, but with much higher stakes, sophisticated investors have risked billions of dollars. History has consistently proven this prediction wrong-leaving a cadre of bewildered academics, embarrassed pundits, and bitter investors in its wake. How could so many leading academics, prestigious pundits, and sophisticated investors be so wrong, for so many decades, about Japan's market for hostile takeovers? This is the enigma of hostile takeovers in Japan, which we seek to explain in this Article.

We argue that, by applying abstract theories derived from the AngloAmerican experience, most Western observers have neglected to properly account for local, idiosyncratic, Japanese factors that have stifled the market for corporate control in Japan. First, Japan transcends and complicates the conventional dispersed/concentrated shareholding dichotomy, as shown by the

\footnotetext{
Copyright (C) 2018 Regents of the University of California

${ }^{\dagger}$ Director, National University of Singapore (NUS) Centre for Asian Legal Studies (CALS), Associate Professor, NUS Law.

${ }^{+\dagger}$ Professor, Faculty of Law, Nagoya University.

*A condensed version of this Article will be published as: Dan W. Puchniak \& Masafumi Nakahigashi, The Enigma of Hostile Takeovers in Japan: Bidder Beware, in COMPARATIVE TAKEOVER REGULATION: Global AND Asian Perspectives (Umakanth Varottil \& Wan Wai Yee eds., Cambridge University Press, forthcoming). We would like to thank the NUS Centre for Asian Legal Studies (CALS) and EW Barker Centre for Law \& Business (EWBCLB) for providing funding to support this research. We would also like to thank all the participants at the Berkeley-NUS-SMU Comparative Corporate Governance Conferences on Comparative Takeover Regulation, which were held at Berkeley Law School and NUS Law, for valuable feedback on earlier drafts. We are particularly grateful to Paul Davies, Gen Goto, Manabu Matsunaka, Curtis Milhaupt, Zenichi Shishido, Holger Spamann, Andrew Tuch, Umakanth Varottil, and Wan Wai Yee for their extremely helpful feedback on earlier versions of this Article. In addition, we would like to sincerely thank Alan K. Koh and Samantha Tang for their highly skillful and invaluable research assistance which went beyond our highest expectations. Some of the material in this Article is adapted from Dan W. Puchniak, The Efficiency of Friendliness: Japanese Corporate Governance Succeeds Again Without Hostile Takeovers, 5 BERKELEY BUS. L.J. 195 (2008) [hereinafter Puchniak, Efficiency of Friendliness]. We are grateful to the Berkeley Business Law Journal for permission to use this material and for their high quality editorial work on this Article. As usual, any errors remain our own.
} 
presence of dispersed stable-shareholders who have consistently rallied in support of incumbent management against hostile acquirers. Second, a corporate and shareholder culture that remains dominated by lifetime employeecontrolled corporate boards adds to the resilience of Japanese companies against hostile takeovers. Third, contrary to the belief of many Western scholars and pundits, Japan's law on defensive measures cannot be easily compared to the UK or US hostile takeover regimes, as it has developed important idiosyncratic features through judicial precedent and corporate practice that have a distinctively anti-takeover flavor. Ultimately, the story of the absence of hostile takeovers in Japan is a cautionary tale to comparative corporate scholars and foreign investors who underestimate the importance of context: apply AngloAmerican generalizations, without adequate local knowledge, at your own peril.

Part I: Introduction 5

Part II: The History of Incorrect Predictions in Context............................10

Part III: Japan's Shareholder Landscape: Complicating The Dispersed

Versus Concentrated Dichotomy.....................................................15

Part IV: The Myopia of the Anglo-American Lens: Understanding Japan's

Regulatory Framework on its Own Terms ....................................22

Japan's foundational hostile takeovers regime-not the UK model

Japan's post-2005 hostile takeovers regime—not the next

Delaware.....

Part V: The Importance of Japan's Unique Corporate Culture: A

Formidable Barrier to Hostile Takeovers 38

Part VI: Avoiding History from Repeating Itself..

\section{PART I: INTRODUCTION}

For over two decades, Japan has ostensibly had all of the essential elements that leading academics and sophisticated investors have assumed to be sufficient for a country to develop an active market for hostile takeovers. ${ }^{1}$ Japan's listed corporations have stood out as having amongst the most dispersed stock ownership in the world. ${ }^{2}$ Listed corporations in Japan have had depressed share

1. Armour, Jacobs, and Milhaupt strongly suggest that the combination of dispersed share ownership, depressed share values, and an Anglo-American regulatory framework will bring about a vibrant market for hostile takeovers. John Armour et al., The Evolution of Hostile Takeover Regimes in Developed and Emerging Markets: An Analytical Framework, 52 HARV. INT’L L.J. 221, 221-23 (2011).

2. In fact, according to the most common empirical measures for shareholder dispersion, only shareholders in the United Kingdom and United States are as dispersed as in Japan-with Japanese shareholders in large public companies appearing even more dispersed on some measures. See Rafael La Porta et al., Corporate Ownership Around the World, 54 J. FIN. 471 (1999); Stijn Claessens et al., The Separation of Ownership and Control in East Asian Corporations, 58 J. FIN. ECON. 81, 82 (2000); 
values relative to their asset values, which has created a plethora of attractive takeover targets. ${ }^{3}$ Moreover, Japan's regulatory framework for hostile takeovers has ostensibly been modelled on the world's two most active markets for hostile takeovers: the United Kingdom in 1990 and then Delaware in 2005. ${ }^{4}$

That Japan purportedly has had a takeover environment with dispersed stock ownership, depressed share values, and a United Kingdom-United Statesinspired regulatory framework, sets it apart (with the United Kingdom and United States) as being ostensibly one of the most hostile takeover-friendly jurisdictions in the world. ${ }^{5}$

MASAHIKO AOKI, CORPORATIONS IN EVOlving Diversity: Cognition, GOVERnANCE, AND InSTITUTIONS (2010); Julian Franks et al., The Ownership of Japanese Corporations in the 20th Century, 27 REV. FIN. STUD. 2580 (2014).

3. It was well recognized that following the burst of Japan's stock market bubble in 1989, a significant percentage of large listed Japanese companies had a cumulative stock price that was considerably less than their bust-up value. This was especially the case when the stock market hit an alltime low in the early 2000s. In 2001, Milhaupt and West reported that thirteen percent of the TSE's nonfinancial companies traded at below their liquidation value. See Curtis J. Milhaupt \& Mark D. West, Institutional Change and M\&A in Japan: Diversity Through Deals 28 (Nov. 18, 2001), https://papers.ssrn.com/sol3/papers.cfm?abstract_id=290744. In the same year, the Economist reported that "there [were] pots of gold hidden everywhere" in Japan as about ten percent of its 3,500 listed companies had break-up values of more than twice their cumulative stock price. See Ever So Polite, ECONOMIST (Feb. 15, 2001), http://www.economist.com/node/507526. In 2005, the Economist Intelligence Unit reported that about 25 percent of Japanese companies had bust-up values less than their cumulative stock price and that these companies were ripe for hostile takeovers as "a faster way to make money [was] hard to find.” See ECONOMIST INTELligenCE Unit, THE BATTLE FOR CORPORATE CONTROL: THE OUTLOOK FOR M\&A IN JAPAN $20 \quad$ (2005), http://graphics.eiu.com/files/ad_pdfs/M_n_A_JP_WP.pdf.

4. In 1990, Japan amended the Securities and Exchange Act. See Shōken torihiki-hō no ichibu wo kaisei-suru hōritsu (証券取引法の一部を改正する法律) [Act Amending the Securities and Exchange Act], Act No. 43 of 1990 (Japan) [hereinafter Act Amending the Securities and Exchange Act (1990)]. This amendment to the Securities and Exchange Act required that an off-exchange offer, the acceptance of which would result in the acquisition of more than 33.3 percent of the target's shares, be made through a tender offer open to all shareholders. Milhaupt and West therefore suggest that the Japanese tender offer regime was "patterned after (but more stringent than)" London's City Code. See Milhaupt \& West, supra note 3, at 19-20. This conclusion, however, seems strained, given that Japan's regime did not have a UKstyle mandatory bid rule because it only required a pro-rata purchase of shares from each shareholder that tendered shares in the offer and did not require the offeror to purchase all outstanding shares prior to obtaining control - which is at the core of the UK mandatory bid rule and London City Code regime. For more details concerning this argument, see infra Part IV. In 2005, the government issued the Takeover Guidelines which, according to many influential scholars, substantially incorporated Delaware takeover jurisprudence regarding defensive measures into Japanese law. See Curtis J. Milhaupt, In the Shadow of Delaware?: The Rise of Hostile Takeovers in Japan, 105 ColuM. L. REV. 2171, 2173 (2005); Dan W. Puchniak, The Efficiency of Friendliness: Japanese Corporate Governance Succeeds Again Without Hostile Takeovers, 5 BERKELEY BUS. L.J. 195, 223-24 (2008). For an English translation of the Takeover Guidelines, see Ministry of ECON., TRADE \& Indus. \& MinistRy OF Just., Guidelines REgARDing TAKeOVEr Defense for the Purposes of Protection AND EnHancement of Corporate VALUE AND SHAREHOLDERS' COMMON INTERESTS http://www.meti.go.jp/policy/economy/keiei_innovation/keizaihousei/pdf/shishin_hontai.pdf [hereinafter TAKEOVER GUIDELINES]. For an overview of the development of the law governing Japanese takeover bids, which takes a slightly different perspective, see Ken'ichi Osugi, What is Converging?: Rules on Hostile Takeovers in Japan and the Convergence Debate, 9 AsIAN-PAC. L. \& POL'Y J. 143, 14956 (2007).

5. See Armour et al, supra note 1. 
This fact has not gone unnoticed. For over two decades, leading academics and prestigious pundits have repeatedly predicted the imminent arrival of a wave of successful hostile takeovers in Japan. ${ }^{6}$ In a similar vein, but with much higher stakes, sophisticated investors have risked billions of dollars on the same prediction. ${ }^{7}$ As we explain in this Article, however, history has consistently proven this prediction wrong-leaving a cadre of bewildered academics, embarrassed pundits, and bitter investors in its wake.

6. In 1989, the CEO of a famous United States merchant bank predicted that, with the globalization of capital markets, value-maximizing investors would use takeovers to replace underperforming managers, change corporate policies, and dramatically restructure companies with the aim of increasing equity value. W. CARL KeSter, JAPANESE TAKeOvers: THE GlobAl CONTEST fOR CORPORATE CONTROL 239 (Harvard Business School Press 1991). He theorized that Japan would be part of this market and therefore be part of a market for corporate control that looked like America's in the 1980s. Id. In his 1991 book, Kester predicted, based on a few failed hostile takeover attempts at the time, that "while it is premature to forecast a convergence of the Japanese market with the West's, these examples make it evident that a newly active market for corporate control in Japan will fill the void left by receding capital market discipline.” Id. In 2001, the Economist reported that “analysts predicted that a new wave of similar [unfriendly] bids might follow. Some even forecast the imminent arrival of an 'Anglo-American' M\&A (mergers and acquisitions) market, where investment banks, company bosses and investors would wrestle for control of companies.” Ever So Polite, supra note 3. In a 2004 article, Gilson reported that “[e]ach report of a reduction in the size of crossholdings among Japanese companies and in the size of Japanese bank stockholdings in their clients has given rise to an expectation that now, at last, hostile offers would emerge.” Ronald J. Gilson, The Poison Pill in Japan: The Missing Infrastructure, 2004 CoLUM. Bus. L. REV. 21, 21 (2004). In the same article, Gilson states that "[a] number of events now suggest that the long wait for hostile transactions in Japan may be approaching its end.” Id. at 22. In his 2005 article, Milhaupt prognosticates that, "[i]f, as now seems distinctly possible, the world's second largest economy is in the process of embracing hostile M\&A (however reluctantly), and along with it the core of Delaware takeover jurisprudence, this development may represent an epochal moment for Japan and for the global standards movement in corporate governance.” Milhaupt, supra note 4, at 2171, 2173-74; see also Say "Hostile Takeover" in Japanese, ECONOMIST (Jul. 17, 1997), http://www.economist.com/node/151924 [hereinafter Say “Hostile Takeover"]; Robert Neff, Japan: Land of the Hostile Takeover?, BLOOMBERG (Mar. 13, 2000), https://www.bloomberg.com/news/articles/2000-03-12/japan-land-of-the-hostiletakeover-intl-edition; Michiyo Nakamoto \& Paul Betts, Hostile Takeover Taboo Will Be Consigned to History, FIN. TIMES (Mar. 2, 2010), https://www.ft.com/content/662aa282-262a-11df-aff3-00144feabdc0.

7. Some of the more prominent failed hostile takeovers are as follows: in March 2005, Livedoor's March 2005 hostile takeover bid for Nippon Broadcasting System; in July 2005, Yumeshin Holdings' hostile takeover bid for Japan Engineering Consultants. See Cristina Alger, The Livedoor Looking Glass: Examining the Limits of Hostile Takeover Bids in Japan, 3 N.Y.U. J.L. \& Bus. 309, 319-20 (2006). In November 2005, Rakuten's hostile takeover bid for Tokyo Broadcasting System failed. See Christopher T. Hines et al., Doing Deals in Japan: An Analysis of Recent Trends and Developments for The U.S. Practitioner, 2006 ColuM. BuS. L. REV. 355, 381-83 (2006). In May 2006, MAC's hostile takeover attempt of Hanshin Electric Railway failed when Hanshin was acquired by Hankyu Holdings, a friendly shareholder. See id. at 383-85. In February 2006, Don Quijote failed in its hostile takeover bid for Origin Toshu, when Origin Toshu's shares were acquired by a friendly shareholder, Aeon. See id. at 436 n.225. In August 2006, Oji Paper's hostile takeover bid for Hokuetsu Paper Mills was defeated. This bid was particularly noteworthy as the defensive measures used by Hokuetsu to defeat the bid appeared to clearly breach the existing hostile takeovers law-yet not a single legal proceeding was commenced even by the foreign shareholders who held a 25 percent stake in Hokuetsu. See Puchniak, supra note 4, at 246-50. In April 2008, Steel Partners sold its stake in Bull-Dog Sauce after its unsuccessful takeover bid for the same in May 2007. See Kenji Hall, Steel Partners Off the Sauce in Japan, Bloomberg (Apr. 18, 2008), https://www.bloomberg.com/news/articles/2008-04-18/steel-partners-off-the-sauce-in-

japanbusinessweek-business-news-stock-market-and-financial-advice; JOHN BUCHANAN ET AL., HEDGE FUnd ACTIVISM IN JAPAN: THE Limits OF SHAREHOLdER PRIMACY 213-23 (2012); Gen Goto, Legally “Strong” Shareholders of Japan, 3 MiCH. J. PRIV. EQUITY \& VENTURE CAP. L. 142, 142 (2014). 
Counterintuitively, Japan's ostensibly takeover-friendly environment has not produced any hostile takeovers. ${ }^{8}$ As this Article reveals, what has made Japan exceptional over the last two decades has been the inability of hostile acquirers to succeed in what many have claimed to be a "hostile takeovers utopia." 9 Moreover, in an ironic twist, during this same period, hostile acquirers have begun to succeed in jurisdictions which have traditionally been viewed as inhospitable to hostile takeovers. ${ }^{10}$ This phenomenon suggests that the criteria for predicting the emergence of an active market for hostile takeovers ${ }^{11}$ requires re-evaluation. In a similar vein, it demonstrates that even if a jurisdiction develops an environment that is ostensibly friendly towards hostile takeovers (i.e., it has dispersed shareholder ownership, depressed share values, and a United Kingdom- or United States-inspired regulatory framework) successful hostile takeovers may not necessarily follow - the opposite of what leading comparative corporate law scholars appear to suggest. ${ }^{12}$

Rather than add to the history of incorrect predictions about the future of hostile takeovers in Japan, this Article seeks to understand them: why have leading academics, prestigious pundits, and sophisticated investors perpetually misunderstood the evolution of hostile takeovers in Japan? We suggest that this misunderstanding emanates from a propensity of academics, pundits, and investors to draw conclusions about the future of hostile takeovers in Japan from abstract theories that they derive primarily from the United States ${ }^{13}$ and United Kingdom experiences. In a similar vein, we also suggest that this misunderstanding is the result of academics, pundits, and investors failing to fully appreciate the importance of local, often idiosyncratic, Japanese factors which cause hostile takeovers in Japan to evolve in a way that the United Kingdom-United States experience or universal comparative corporate governance theories would not predict. ${ }^{14}$ As such, one of the objectives of this

8. Puchniak, supra note 4, at 200.

9. David Turner, Takeover Advisor to Target Japan, FIN. TIMES, Jun. 21, 2005; KESTER, supra note 6, at 239; Gilson, supra note 6, at 21-22; Ever So Polite, supra note 3; Puchniak, supra note 4, at 201.

10. Until 1999, Germany was the only other major economy without a successful hostile takeover bid. This changed-spectacularly-when Vodaphone was victorious in its hostile takeover of Mannesmann. However, Germany has traditionally opposed hostile takeovers because it places emphasis on the protection of other constituencies-especially employee interests-to preserve social cohesion, which might be negatively affected by hostile takeovers. For more information on hostile takeovers in Germany, see REINIER KRAAKMAN ET AL., THE ANATOMY OF CORPORATE LAW: A COMPARATIVE AND FUNCTIONAL APPROACH 271 (2d ed. 2009).

11. Puchniak, supra note 4, at 224-225, 224 n. 170.

12. Milhaupt, supra note 4, at 2215-16; Armour et al., supra note 1, at 284-85.

13. Puchniak, supra note 4, at 224-225.

14. Id. at 205-209. However, leading corporate scholars have recently recognized that factors which might explain the differences between takeover regimes in the United States and the United Kingdom "partially, but do not completely," explain the features of the Japanese approach, and have adopted an analytical framework that seeks to acknowledge the presence of such idiosyncratic factors. See Armour et al., supra note 1 , at 270-273. 
Article is to explain the commonly overlooked local factors that have resulted in hostile takeovers in Japan being misunderstood.

In addition, by revealing the imperative role of local factors, this Article contributes to an emerging body of scholarship in comparative corporate law which suggests that local factors-rather than universal theories of comparative corporate governance-are the key to properly understanding corporate law comparatively. ${ }^{15}$ This Article further suggests that the imperative role of local factors in uniquely stifling the development of hostile takeovers in Japan supports the conclusion that the global convergence of corporate law remains largely an academic proposition with limited applicability in actual practice. ${ }^{16}$

The balance of this Article proceeds as follows: Part II chronicles the historical and economic context which gave rise to the history of incorrect predictions about the imminent arrival of successful hostile takeovers in Japan. Part III examines Japan's complex and often misunderstood shareholder ownership landscape and suggests why an understanding that goes beyond the traditional dispersed versus concentrated shareholder ownership dichotomy is necessary to make sense out of the failure of hostile takeovers in Japan. Moreover, Part III explains how ostensibly depressed share values create a mirage of attractive hostile takeover targets in Japan which disappear when the "true value" of shares in listed companies in Japan is properly understood. Part IV explains the legal framework governing hostile takeovers in Japan and highlights why, despite it being loosely inspired by the United Kingdom and then Delaware, it has important differences from both models and has served (and still serves) as a formidable barrier to developing a vibrant market for hostile takeovers. Part V highlights how Japan's lifetime employee-dominated corporate and shareholder culture may be as important, if not more important, than any other factor in explaining the lack of successful hostile takeovers in Japan. Part VI concludes by summarizing the main findings of this Article, with the hope of preventing the history of incorrect predictions about hostile takeovers in Japan from repeating itself.

15. Dan W. Puchniak, The Derivative Action in Asia: A Complex Reality, 9 Berkeley Bus. L.J. 1 (2012); see also Dan W. Puchniak \& Kon Sik Kim, Varieties of Independent Directors in Asia: A Taxonomy, in InDEPENDENT DiRECTORS IN ASIA: A HistoriCAL, CONTEXTUAL AND COMPARATIVE Approach 89 (Dan W. Puchniak et al. eds., 2017); Dan W. Puchniak \& Luh Luh Lan, Independent Directors in Singapore: Puzzling Compliance Requiring Explanation, 65 AM. J. COMP. L. 265 (2017).

16. Dan W. Puchniak, The Japanization of American Corporate Governance?: Evidence of the Never-Ending History for Corporate Law, 9 AsIAN-PAC. L. \& POL’y J. 7 (2007). For an excellent current analysis of the convergence debate, which explains how there is "divergence in convergence" see, Jeffrey N. Gordon, Convergence and Persistence in Corporate Law and Governance (Dec. 12, 2017). Oxford Handbook of Corporate Law and Governance (Jeffrey Gordon \& Georg Ringe eds.), forthcoming; Columbia Law and Economics Working Paper No. 574. Available at SSRN: https://ssrn.com/abstract=3037113. 


\section{PART II: THE HISTORY OF INCORRECT PREDICTIONS IN CONTEXT}

After almost three decades of tepid economic growth, it is easy to forget that in the late 1980s Japan was, by many measures, the richest country in the world. ${ }^{17}$ It had the highest per capita Gross National Product, largest net holdings of foreign assets, and by far the largest stock market capitalization and highest property values in the world. ${ }^{18}$ Japan's rise to the zenith of the world economy was even more extraordinary considering that merely a few decades earlier its devastating defeat in World War II had reduced it to the level of a poor developing country. ${ }^{19}$

Many experts cite Japan's main bank corporate governance model as a key to its remarkable post-war economy. ${ }^{20}$ The main bank model is based on banks being the most important corporate monitors, with hostile takeovers and other shareholder-based monitoring playing almost no role. The other two key components of the model are cross shareholding (keiretsu) and lifetime employment, which both act to insulate management from external market-based monitoring. ${ }^{21}$ However, contrary to popular belief, Japan's main bank model was not marked by an absence of mergers and acquisitions (M\&A). During the 1950s, Japan had approximately 500 M\&A transactions per year, and by 1985, the number had increased to approximately 2,000 per year. ${ }^{22}$ Indeed, for most of the 1980s, when America was experiencing an M\&A boom, the rate of combinations per 10,000 companies was higher in Japan than in the United States. ${ }^{23}$

Rather, the oddity of Japan's highly successful post-war main bank modelespecially when compared with American corporate governance in the 1980swas its lack of hostile takeovers. In the decades following the war, all of the large-scale M\&A in Japan were either friendly or orchestrated by the government (something which still holds true today). ${ }^{24}$ Indeed, in Japan's friendly post-war

4.

17. Material in this section has been updated and condensed from portions of Puchniak, supra note

18. TAKATOSHI Ito, The JAPANESE ECONOMY 3-4 (1992).

19. Michael Spence, The NeXt Convergence: The Future of Economic Growth in A MulTiSPEED WORLD 14 (2011).

20. See ITO, supra note 18, at 369; Michael E. Porter, Capital Disadvantages: America's Failing Capital Investment System, 70 HARV. Bus. REV. 65 (1992); Roberto Romano, Corporate Law and Corporate Governance, 5 INDUS. \& CORP. CHANGE 277, 297-313 (1996).

21. See generally Masahiko Aoki, The Japanese Main Bank System: An Introductory Overview, in THE JAPANESE MAIN BANK SySTEM: ITS RELEVANCE FOR DEVELOPING AND TRANSFORMING ECONOMIES 1-50 (Masahiko Aoki \& Hugh Patrick eds., 1994) [hereinafter THE JAPANESE MAIN BANK SYSTEM] (providing a concise explanation of the classic Japanese main bank model); Dan W. Puchniak, The 2002 Reform of the Management of Large Corporations in Japan, 5 AUSTL. J. ASIAN L. 42, 46 (2003).

22. See KESTER, supra note 6, at 8 n.1, 83.

23. Id. at 83 .

24. According to Kester, in the post-war period until the burst of the bubble in 1990, the large-scale mergers that did occur were friendly deals that were sanctioned by the government and/or main banks and between related companies. The purpose of the mergers was normally a "deliberate [attempt] to alter the structure and performance of the industries in which the mergers occurred.” Id. at 94. In most cases, the government and main banks orchestrated the mergers to: (1) reduce excess capacity; (2) avoid destructive 
corporate governance environment, legislation governing takeover bids did not even exist until the 1971 Amendment to the Securities and Exchange Act. ${ }^{25}$ Under this regime, only two friendly takeover bids were registered and concluded prior to its amendment in $1990 .^{26}$

In stark contrast, in the 1980s, the overarching view was that hostile takeovers were driving American corporate governance. At that time, hostile bids were received by over half of all major American companies and viewed as the central mechanism for controlling agency costs and driving America's successful restructuring. ${ }^{27}$ In 1988 alone, there were twenty-seven successful hostile takeovers of large listed companies in the United States. ${ }^{28}$ Thus, in the 1980s and early 1990s, the obvious question, especially for American academics, was: how did Japan engineer the world's most efficient economy without hostile takeovers?

Prior to the burst of Japan's economic bubble in 1990, the answer was simple: Japan did not have hostile takeovers because it did not need them. ${ }^{29}$ The main bank model provided an effective system for mitigating shareholder-manager agency costs and driving efficient restructuring — which many have traditionally seen as the two primary benefits of hostile takeovers. ${ }^{30}$ As such, the main bank model was widely viewed as making hostile takeovers unnecessary in Japan because it performed the same functions as hostile takeovers but in a manner that experts suggested was more efficient. ${ }^{31}$ Moreover, some experts posited that introducing hostile takeovers into post-war Japan would have broken the web of "friendly efficiency" 32 that allowed its economy to consistently outperform all others for over three consecutive decades following the war. ${ }^{33}$

price competition; (3) build domestic firms to the scale that they can compete internationally; and/or (4) combine weaker firms with stronger ones. Id; see also Puchniak, supra note 4.

25. Shōken-torihiki-hō no ichibu wo kaisei suru hōritsu (証券取引法の一部を改正する法律) [Act Amending the Securities and Exchange Act], Act No. 4 of 1971 (Japan).

26. The Securities and Exchange Act was subsequently amended in 1990. See KESTER, supra note 6, at 99 .

27. Bengt Holmstrom \& Steven N. Kaplan, Corporate Governance and Merger Activity in the United States: Making Sense of the 1980s and 1990s, 15 J. ECON. PERSP. 121, 125 (2001).

28. See John C. Coates IV, Measuring the Domain of Mediating Hierarchy: How Contestable Are U.S. Public Corporations?, 24 J. CORP. L. 837, 855-56 (1999) (reporting that 32 percent of the 85 hostile bids in 1988 were successful).

29. According to Kester, the Japanese system of corporate governance "largely obviated the necessity for a deep and active market for corporate control at home, limited the activity of Japanese companies in the market abroad, and yielded a paucity of attractive targets for foreign bidders.” KESTER, supra note 6, at 5; see also Milhaupt \& West, supra note 3.

30. One of us has described this in detail elsewhere. See generally Puchniak, supra note 4.

31. Masahiko Aoki \& Hugh Patrick, Introduction to THE JAPANESE MAIN BANK SYSTEM, supra note 21, at xxi-xxxii; Takeo Hoshi et al., Lessons from the Japanese Main Bank System for Financial System Reform in Poland, in THE JAPANESE MAIN BANK SYSTEM, supra note 21, at 593-94, 611. On relational investing, see generally Romano, supra note 20, at 297-313.

32. As coined in Puchniak, supra note 4.

33. Masahiko Aoki, Monitoring Characteristics of the Main Bank System: An Analytical and Developmental View, in THE JAPANESE MAIN BANK SySTEM, supra note 21, at 138. 
In 1990, however, Japan's celebrated main bank model came crashing down with the burst of its economic bubble. On the last day of business in 1989, the Nikkei 225 stock price index reached its 38,915 peak, and then collapsed. The Nikkei declined by almost 50 percent in nine months, and by October 1, 1990, it hovered barely above 20,000. For the balance of the 1990s, which came to be known as the "lost decade," the Nikkei floated around 15,000. The Nikkei entered the new millennium with a brief climb up to 20,000 and then, on April 28, 2003, plummeted again to near its post-war low of 7,607. Finally, after the Global Financial Crisis (GFC) on March 10, 2009, the Nikkei hit its all-time post-war low of 7,054-which was 81.9 percent below its peak twenty years earlier. ${ }^{34}$ It nearly repeated this low in 2011 after Japan's massive earthquake and tsunami, which brought about a nuclear meltdown with serious repercussions. ${ }^{35}$ Most recently, driven by the economic policies of Prime Minister Shinzo Abe, often referred to as "Abenomics", the Nikkei climbed to above $20,000^{36}$ but then fell to around 16,000 , and it still remains at far less than half of its bubble peak. ${ }^{37}$

The burst of the stock market bubble, coupled with a similar collapse of Japan's real estate market, had a devastating impact on the Japanese economy. During the lost decade that followed, the economy slipped into negative growth, and price deflation placed a stranglehold on domestic investment and spending. As a result, the famed Japanese banking system amassed mountains of nonperforming loans and had capital ratios that were on the verge of falling below the regulatory minimums required to keep its doors open. ${ }^{38}$ The entire banking system would likely have fallen into complete chaos if not for the Japanese government's forced bank mergers and bailouts. ${ }^{39}$ The government's role as the backstop for failing banks and its pump-priming spending resulted in massive

34. Michael Hutchison et al., Empirical Determinants of Banking Crises: Japan's Experience in International Perspective, Why did Japan Stumble?, in WHY DID JAPAN STUMBLE?: CAUSES AND CURES 157 (Craig Freedman ed., 1999); see also Takeo Hoshi \& Anil K. Kashyap, Japan's Financial Crisis and Economic Stagnation, 18 J. ECON. PERSP. 3, 5 (2004); Kathleen Chu \& Kazue Somiya, Buying Spree for GE Real Estate: Its Japanese Property Holdings May Increase 60\% This Year, BLOOMBERG, Aug. 27, 2007; Time to Arise from the Great Slump, ECONOMIST (Jul. 20, 2006), http://www.economist.com/node/7189583.

35. Alex Hawkes, World Stock Markets Slide on Japan Panic, GuARdiAn (Mar. 15, 2011), https://www.theguardian.com/business/2011/mar/15/stock-markets-slide-japan-panic.

36. Josh Noble \& Ralph Atkins, Nikkei 225 Passes 20,000 After 15-Year Wait, Fin. TimES (Apr. 22, 2015), https://www.ft.com/content/762b3682-e8c2-11e4-87fe-00144feab7de.

37. Saheli Roy Choudhury, Asia Markets Post Weekly Gains as Investors Digest Chinese GDP Data, CNBC, Jul. 15, 2016.

38. The Non-Performing Country, ECONOMIST (Feb. 15, 2002), http://www.economist.com/node/996898.

39. Gillian Tett, Saving the Sun: A Wall Street Gamble to Rescue Japan From Its TriLlion-Dollar MELTdOWn xxiv-xxv (2003); see also Chronic Sickness, ECONOMIST (May 31, 2001), http://www.economist.com/node/639516; The Viagra Economy, ECONOMIST (Sep. 22, 2005), http://www.economist.com/node/4418402; Dan W. Puchniak, Perverse Main Bank Rescue in the Lost Decade: Proof that Unique Institutional Incentives Drive Japanese Corporate Governance, 16 PAC. RIM L. \& POL'Y J. 13 (2007). 
deficits that were unmatched by any other developed country. ${ }^{40}$ During the darkest days of the lost decade, questions arose as to whether Japan's position as one of the world's leading economies might quickly slip away. Despite an underappreciated period of economic recovery in the mid-2000s (which the GFC extinguished) and, more recently, a spark of economic hope as a result of Abenomics, serious questions still linger about the future of the Japanese economy. ${ }^{41}$

In this context, it is understandable why, starting in the 1990s, many experts wrote off the main bank model as an economic system that had outlived its usefulness. ${ }^{42}$ Relatedly, after the burst of the bubble, many M\&A experts viewed Japan as strikingly similar to the United States during the 1980s in terms of its need for restructuring. Experts viewed Japan's conglomerate groups (keiretsu) as tantamount to the inefficient conglomerates in the United States, which hostile takeovers effectively dismantled during the 1980s. ${ }^{43}$ During the lost decade, main banks reportedly kept legions of inefficient industries and "zombie firms" on life support. ${ }^{44}$ As such, it appeared to many academics, pundits and investors that, similar to the United States in the 1980s, shareholders in Japan would stand to gain from hostile takeovers, which would force entrenched managers to either focus on shareholder value or be culled from the market.

In addition, and perhaps most importantly, since the burst of the bubble, the bust-up values of a substantial portion of Japan's large listed companies have reportedly been above their cumulative stock prices ${ }^{45}$-a phenomenon that, in

40. Puchniak, supra note 4, at 210.

41. STEVEN K. VOGEL, JAPAN REMODELED: HOW GOVERNMENT AND INDUSTRY ARE REFORMING JAPANESE CAPITALISM 27 (2007); Shingo Miyake, New Corporate Law Caps Series of Business Reforms, NIKKEI WKLY., May 8, 2006; In Jeopardy, ECONOMIST (Aug. 13, 2015), https://www.economist.com/news/finance-and-economics/21661030-shinzo-abes-sliding-popularityputting-abenomics-risk-jeopardy; Yoshiaki Nohara \& Andy Sharp, Abenomics is Losing Support with Economists and Voters Alike, BLOOMBERG MKTS. (Mar. 17, 2016), https://www.bloomberg.com/news/articles/2016-03-07/abenomics-is-losing-support-with-economistsand-voters-alike; William Pesek, Abenomics Failure Explained, JAPAN TIMES (Apr. 4, 2016), https://www.japantimes.co.jp/opinion/2016/04/04/commentary/japan-commentary/abenomics-failureexplained/\#.Wn5IIGaZMmU.

42. James C. Abegglen, 21st Century Japanese Management: NeW Systems, Lasting VALUES 131 (2006); Vogel, supra note 41, at 1-2, 205; Ronald J. Gilson, Globalizing Corporate Governance: Convergence of Form or Function, 49 AM. J. COMP. L. 329, 331 (2001); Yoshiro Miwa \& J. Mark Ramseyer, The Myth of the Main Bank: Japan and Comparative Corporate Governance, 27 L. \& SOC. INQ. 401, 409 (2002) (reviewing MASAHIKO AOKI, INFORMATION, CORPORATE GOVERNANCE, AND INSTITUTIONAL DIVERSITY: COMPETITIVENESS IN JAPAN, THE USA, AND THE TRANSITIONAL ECONOMIES xiii, 186 (Stacey Jehlik trans., 2000)); see also Curtis J. Milhaupt, On the (Fleeting) Existence of the Main Bank System and Other Japanese Economic Institutions, 27 L. \& Soc. INQ. 425, 428 (2002) (arguing that the main bank system was part of a team of institutions forged in the post-war era that needed to evolve to meet new challenges).

43. Gilson, supra note 6, at 24-25; Challenging Japan's Cozy Corporate Culture, TIME (Feb. 7, 2000), http://content.time.com/time/world/article/0,8599,2054366,00.html; see also VoGEL, supra note 41, at 144-45; Holmstrom \& Kaplan, supra note 27, at 130.

44. Puchniak, supra note 4 , at 215.

45. Low Price-to-Book Ratios May Reveal Undervalued Japanese Stock, NIKKEI ASIAN REV. (May 14, 2014), https://asia.nikkei.com/Markets/Equities/Low-price-to-book-ratios-may-reveal-undervalued- 
the late 1980s, drove a wave of hostile takeovers in the United States and which has been linked to the rise of hostile takeovers in the United Kingdom. ${ }^{46}$ In 2001, Milhaupt and West reported that 13 percent of the Tokyo Stock Exchange's nonfinancial companies traded below their liquidation value. ${ }^{47}$ In the same year, The Economist reported that "there [were] pots of gold hidden everywhere" in Japan, as about 10 percent of its 3,500 listed companies had break-up values of more than twice their cumulative stock price. ${ }^{48}$ In 2005, the Economist Intelligence Unit reported that about 25 percent of Japanese companies had bust-up values of more than their cumulative stock price and that these companies were ripe for hostile takeovers as "a faster way to make money [was] hard to find." 49 In the words of one M\&A commentator, "[i]f there are profits to be had, hostile takeovers will increase ... this cannot be stopped, even if it doesn't suit Japan's culture." ${ }^{50}$ As such, many assumed that the potential to make enormous profits in Japan's undervalued and dispersed stock market would axiomatically lead to a wave of American-style hostile takeovers during Japan's lost decade. Further bolstering this view were the opinions of leading academics and pundits who suggested that the Japanese government's issuance of the Takeover Guidelines in 2005 substantially incorporated Delaware takeover jurisprudence into Japanese law-combining the legal framework from the world's leading jurisdiction for hostile takeovers with Japan's optimal market conditions for hostile takeovers. ${ }^{51}$

Ultimately, however, as noted above, there still has not been a single successful hostile takeover in Japan. ${ }^{52}$ This extraordinary fact stands in the face

Japanese-stock; Mia Tahara-Stubbs, Japan Inc Shopping Spree Just Beginning: Goldman, CNBC (Apr. 8, 2015), https://www.cnbc.com/2015/04/08/japan-inc-shopping-spree-just-beginning-goldman.html.

46. Armour et al., supra note 1, at 240 n.98.

47. Milhaupt \& West, supra note 3, at 28.

48. Ever So Polite, supra note 3.

49. ECONOMIST INTELLIGENCE UNIT, supra note 3, at 20.

50. Michiyo Nakamoto, A Takeover Battle Launched by the Upstart Livedoor is a Test of How Much Big Corporate Groups Can Protect Themselves Against Unwanted Attention, Fin. TiMES, Mar. 22, 2005.

51. Milhaupt, supra note 4, at 2173; see also TAKEOVER GUIDELINES, supra note 4.

52. Puchniak, supra note 4, at 200; Mariko Sanchanta, Failed Takeover Bid by Oji Seen as Loss for Hokuetsu, INT'L HERALD TRIB., Sep. 6, 2006. In addition to hostile takeover attempts failing to succeed, despite Japanese dispersed shareholder structure all forms of hedge fund activism (which include, but go beyond, hostile takeover attempts) have been largely unsuccessful. Gen Goto, in his review of hedge fund activism in Japan since the 2000s, concluded that "[p]utting aside the possibility of future developments, hedge fund activism seems to have largely failed as a sustainable investment strategy thus far." Goto, supra note 7 , at 142 . Observers have also noted that "[d]eeply ingrained biases linger, meaning nonJapanese buyers are still few and far between, and hostile takeovers remain mainly theoretical.” See Sharon Kahn, Why M\&A is Different in Japan, Colum. Bus. ScH. CHAzEN GlobAl Insights, Jan. 5, 2015, http://beta.global.columbia.edu/global-news/why-ma-different-japan. A Japanese proxy adviser at International Shareholder Services, Inc. also noted that "[h]ostile takeovers in Japan are like plane crashes. They hardly ever happen. . . . Yet Japanese corporations are afraid and want to protect themselves." Yuko Takeo, Japanese Firms Cling onto Shareholding 'Poison Pills,' Snubbing Abe's Governance Push, JAPAN Times (Jul. 29, 2015), https://www.japantimes.co.jp/news/2015/07/29/business/economybusiness/japanese-firms-cling-onto-shareholding-poison-pills-snubbing-abes-governancepush/\#.Wn5F_GaZMmU. 
of repeated predictions by leading academics ${ }^{53}$ and prestigious pundits ${ }^{54}$ who have claimed for decades that a wave of successful hostile takeovers in Japan was imminent. Moreover, it belies the efforts of numerous sophisticated domestic and international activist investors who, over the last two decades, have made several valiant attempts to succeed in hostile takeover bids-but who have all ultimately failed in their attempts. ${ }^{55}$

How could so many leading academics, prestigious pundits, and sophisticated investors be this wrong about Japan's market for hostile takeovers for decades? How has corporate Japan managed to keep hostile takeovers from occurring despite Japan having an environment that is ostensibly a "utopia for hostile takeovers"? This is the enigma of hostile takeovers in Japan. Our goal in the remainder of this Article is to explain it.

\section{PART III: JAPAN'S SHAREHOLDER LANDSCAPE: COMPLICATING THE DISPERSED VERSUS CONCENTRATED DICHOTOMY}

In the comparative corporate law and governance literature, whether a jurisdiction has a dispersed or concentrated shareholder landscape is often viewed as the most important determinant of whether it will develop a vibrant market for hostile takeovers. ${ }^{56}$ This makes sense; hostile takeovers are only possible in companies without a controlling block-shareholder. As such, in jurisdictions where most listed companies have a controlling block-shareholder, hostile takeovers will only be possible in a small fraction of companies. In these jurisdictions, hostile takeovers are likely to be extremely rare and to have a relatively limited impact on corporate governance.

Compared to most other countries, Japan stands out, along with the United States and United Kingdom, for having a dispersed shareholder landscape. ${ }^{57}$ On average, over the last several decades, approximately 10 percent of Tokyo Stock Exchange (TSE) listed companies have had a controlling block shareholder. ${ }^{58}$ As

53. Gilson, supra note 6, at 21-22 ("The coming of hostile takeovers to Japan has been anticipated, and anticipated, and anticipated. Each report of a reduction in the size of crossholdings among Japanese companies and in the size of Japanese bank stockholdings in their clients has given rise to an expectation that now, at last, hostile offers would emerge. . . . A number of events now suggest that the long wait for hostile transactions in Japan may be approaching its end.”); KESTER, supra note 6, at 239; Milhaupt, supra note 4, at 2189 ("As we have seen, substantial market shifts and large-scale legal development occurred over the course of a decade, in a country commonly portrayed as slow to change, culminating in a series of hostile bids that would have seemed unthinkable a short time ago.”).

54. Say "Hostile Takeover," supra note 6; Ever So Polite, supra note 3; Nakamoto \& Betts, supra note 6.

55. For a detailed list of failed hostile takeover bids, see supra note 7 and accompanying text.

56. Armour et al., supra note 1, at 221-222; see also David C. Donald, Evolutionary Development in Hong Kong of Transplanted UK-Origin Takeover Rules, in COMPARATIVE TAKEOVER REgULATION: GLOBAL AND Asian PERSPECTIVEs (Umakanth Varottil \& Wan Wai Yee eds., forthcoming) [hereinafter COMPARATIVE TAKEOVER REGULATION].

57. La Porta et al., supra note 2; Claessens et al., supra note 2; AOKI, supra note 2; Franks et al., supra note 2 .

58. Franks et al., supra note 2, at 2592 tbl.3. 
such, hostile takeovers have been technically possible in the vast majority of listed companies in Japan for decades. This market reality distinguishes Japan, along with the United States and United Kingdom, from almost every other jurisdiction in the world. ${ }^{59}$

While the dispersed versus concentrated shareholder dichotomy provides a useful starting point for explaining why the United States and United Kingdom have had the most active markets for hostile takeovers in the world, this dichotomy has limited explanatory force for Japan. Ironically, it appears that grouping Japan with the United States and United Kingdom on the basis of their dispersed shareholder landscape has resulted in at least three distinct, but interrelated, misunderstandings about Japan's hostile takeovers market.

First, it appears that classifying Japan in this manner has led some observers and market players to assume that Japan would axiomatically develop a market for hostile takeovers. ${ }^{60}$ As suggested above, this assumption is incorrect because the fact that a jurisdiction has a dispersed shareholder landscape merely means that hostile takeovers are technically possible in most of its listed companies. It provides no information about whether hostile takeovers will actually be attempted or ultimately succeed. Japan demonstrates that a dispersed shareholder landscape may be necessary for a jurisdiction to develop an active market for hostile takeovers, but it is insufficient on its own.

Second, this classification unduly focuses on the shareholder landscape of the Japanese stock market as a whole, rather than on the specific identities of the various types of dispersed shareholders and the different types of companies that may be potential takeover targets. This narrow focus on the shareholder landscape of the Japanese stock market as a whole is misplaced because hostile takeovers ultimately occur at the firm and not the market level. This misunderstanding has resulted in a myopic understanding of Japan's hostile takeovers market, as there has been a pervasive failure to appreciate critical attributes of certain sub-categories of dispersed shareholders ${ }^{61}$ and the diverse nature of potential target companies-both of which, as explained below, have had an important impact on the evolution of Japan's hostile takeovers market.

Third, the realization that Japan has a dispersed shareholder landscape has caused many observers to assume that a market for hostile takeovers in Japan will evolve in a way that is similar to that of the United States and United Kingdom. ${ }^{62}$ This assumption has provided the theoretical underpinning for the persistent predictions that Japan will develop an active market for hostile takeovers. As explained in detail below, a litany of complex shareholder-market,

59. Armour et al., supra note 1 , at 222.

60. See Neff, supra note 6; Gilson, supra note 6, at 21, 29; Milhaupt, supra note 4, at 2171, 2173-74; Say “Hostile Takeover," supra note 6; Ever So Polite, supra note 3; Nakamoto \& Betts, supra note 6.

61. Puchniak, supra note 16, at 41-42.

62. Milhaupt, supra note 4, at 2175; see also Armour et al., supra note 1, at 284-85. 
legal, and cultural factors have caused Japan's hostile takeovers market to evolve in ways that are often the opposite of the evolution of the hostile takeovers markets in the United States and United Kingdom. The fact that many of these complex factors appear to be unique to Japan and are continually evolving suggests that comparisons between the market for hostile takeovers in Japan and the United States-United Kingdom are problematic.

Taken together, these misunderstandings all result from Japan erroneously being classified as a country with a "dispersed shareholder landscape" based on the overly blunt dispersed versus concentrated shareholder dichotomy. These misunderstandings also help explain why many observers have erroneously assumed that Japan would develop a vibrant market for hostile takeovers. The remainder of this Part of the Article will explain why Japan's ostensibly dispersed shareholder market must be viewed as unique and cannot be categorized together with the United States and United Kingdom based on the blunt dispersed versus concentrated dichotomy. In doing so, it will illustrate why a blunt dispersed versus concentrated shareholder ownership dichotomy is misleading and why understanding the specific identities of different types of dispersed shareholders is important for accurately understanding hostile takeovers in Japan (and, we suspect, elsewhere).

There are three unique aspects of Japan's dispersed shareholder landscape that help explain why it has not developed a vibrant market for hostile takeovers. First, Japanese corporate governance experts have consistently observed that most of the listed companies in Japan contain a distinct subset of dispersed shareholders, which are commonly referred to as "stable-shareholders."63 These stable-shareholders generally consist of banks, insurance companies, or other non-financial Japanese companies that are "typically engaged in some sort of business transaction with the issuer corporation." ${ }^{64}$ Stable-shareholders normally hold a small percentage (usually less than 5 percent) ${ }^{65}$ of the issuer corporation's shares for the purpose of maintaining a long-term business relationship with the issuer corporation. Contrary to the typical dispersed shareholder, stableshareholders do not purchase shares in the issuer corporation for the purpose of receiving dividends and/or realizing capital gains. ${ }^{66}$

63. A "stable shareholder" has been described as "[a person who] holds the shares as a 'friendly" insider sympathetic to incumbent management: agrees not to sell the shares to third parties unsympathetic to incumbent management, particularly hostile takeover bidders or bidders trying to accumulate strategic parcels of shares: agrees, in the event that disposal of the shares is necessary, to consult the firm or at least give notice of its intention to sell.” See Ronald J. Gilson, Reflections in a Distant Mirror: Japanese Corporate Governance Through American Eyes, 1998 ColuM. Bus. L. REV. 203, 209 n.19 (1998) (citing Paul Sheard, Interlocking Shareholdings and Corporate Governance, in THE JAPANESE FIRM: THE SOURCES OF COMPETITIVE STRENGTH at 314, 318 (Masahiko Aoki \& Ronald Dore eds., 1996).

64. Goto, supra note 7, at 142; see also Puchniak, supra note 16, at 42.

65. La Porta et al., supra note 2, at 492, 496-97; Claessens et al., supra note 2, at 103; Puchniak, supra note 16 , at 42 .

66. Goto, supra note 7 , at 142. 
When faced with a hostile takeover bid with a significant premium, stableshareholders have little incentive to sell their shares given that they are not looking to reap capital gains through their shareholding. On the contrary, they have a strong incentive to support incumbent management to maintain a solid business relationship with the issuer corporation. Understanding these incentives illuminates why a hostile takeover bid, which offers a significant premium to a typical dispersed-shareholder, may in fact be seen by a stable-shareholder as offering a negative premium. For the stable-shareholder, the "true value" of the shares is not solely the market price, but the market price plus the value of maintaining a business relationship with the target company (which may be worth more to the stable-shareholder than the "premium" offered). In such a case, it would be rational for a stable-shareholder to reject a hostile takeover bid with a "substantial premium", even though it would be rational for a typical (nonstable) dispersed shareholder to accept the bid in the same situation.

In 1985, the percentage of stable-shareholdings in TSE listed companies peaked at 66.1 percent of total market value and remained above 50 percent until 1999. ${ }^{67}$ As such, stable-shareholdings explain why in the build-up to Japan's economic bubble in the late 1980s and in the decade after its burst in the 1990s, despite sporadic hostile takeover attempts, none of them succeeded. It is also clear why the significant decline in stable-shareholdings in the late 1990s and early 2000s (i.e., stable shareholdings declined from 53.5 percent in 1997 to 32.9 percent in 2006) — which largely occurred as a result of financially distressed stable-shareholders being forced to sell shares to raise capital—spurred leading academics and prestigious pundits to once again predict that Japan would develop a vibrant market for hostile takeovers. ${ }^{68}$ In the early-to-mid 2000s, it appeared as if these predictions would finally become a reality as there was an unprecedented number of hostile takeover bids. ${ }^{69}$ This development, coupled with the fact that stable-shareholdings consistently remained below 50 percent throughout the $2000 \mathrm{~s},{ }^{70}$ appeared to make Japan a "utopia for hostile takeovers".

The fact that all of the hostile takeover attempts failed in this ostensible utopia, once again, belied the experts' predictions that Japan would likely become something akin to another Delaware. ${ }^{71}$ Moreover, in the late 2000s,

67. TOKYO STOCK EXCHANGE, INC., 2015 SHARE OWNERSHIP SURVEY http://www.jpx.co.jp/english/markets/statistics-equities/examination/b5b4pj00000154dp-att/e-

(2016), bunpu2015.pdf.

68. Gilson, supra note 6, at 22; KESTER, supra note 6, at 239; Milhaupt, supra note 4, at 2189.

69. However, comparing hostile takeover bids in Japan with the United States is essentially comparing "apples and oranges" in light of the substantive differences between the two. As such, many takeover bids in Japan were deemed to be "hostile takeover bids" according to United States criteria, even though such bids should not have been deemed as such. Puchniak, supra note 4, at 251-54.

70. TокYо STOCK EXCHANGE, INC., supra note 67.

71. Milhaupt, supra note 4, at 2215-16. 
following several highly publicized failed hostile takeovers ${ }^{72}$ and the GFC, ${ }^{73}$ Japan's hostile takeover market went virtually silent. ${ }^{74}$ Although stableshareholdings in TSE listed companies reached a low in 2015 of 31.4 percent, ${ }^{75}$ hostile takeover attempts remained moribund and are currently in a state of slumber. ${ }^{76}$ The failure of Japan's hostile takeovers market to develop, despite the significant reduction in stable-shareholdings, presents a conundrum. ${ }^{77}$

To begin to unravel this conundrum requires a more granular analysis of Japan's shareholder ownership landscape - which reveals the second unique aspect of Japan's dispersed shareholder market. Gen Goto, in his recent research on shareholder activism in Japan, insightfully notes that the reduction in stableshareholdings has not occurred evenly among TSE listed companies. ${ }^{78}$ As Goto explains, in the late-1990s, when banks were forced to sell their stableshareholdings to meet regulatory capital requirements, they strategically sold shares in corporations with larger market capitalization and higher market valuation. This was done to refrain whenever possible from selling shares of corporations that were dependent on the banks for borrowing, with a view to preserving important main-bank relationships. ${ }^{79}$

As a result, much of the decrease in stable-shareholdings was concentrated in the largest TSE listed companies, meaning that stable-shareholdings still remained relatively high in small and medium sized listed companies. ${ }^{80}$ As small and medium sized listed companies tend to be more vulnerable to hostile

72. Puchniak, supra note 4, at 243-50; BUCHANAN ET AL., supra note 7, at 213-24.

73. Goto, supra note 7, at 140 .

74. BUCHANAN ET AL., supra note 7, at 180. M\&A practitioners in Japan have observed that "[they had] not seen much of either [shareholder activism or hostile takeovers] since the global financial crisis.” See Japan: An Interview with Ryuji Sakai and Kayo Takigawa, GetTing THE DEAL Through, https://gettingthedealthrough.com/intelligence/34/article/4577/mergers-acquisitions-japan (last visited July 21, 2016) [hereinafter An Interview with Ryuji Sakai and Kayo Takigawa].

75. TOKYO STOCK EXCHANGE, INC., supra note 67.

76. An Interview with Ryuji Sakai and Kayo Takigawa, supra note 74.

77. A 2004 article by Gilson suggested that there would be a rise in hostile takeovers following reports of reductions in stable-shareholdings among Japanese companies and Japanese bank stockholdings in their clients, but the increase did not materialize. See Gilson, supra note 6, at 21-22; Puchniak, supra note 4 , at 224 .

78. Goto, supra note 7, at 145-147.

79. Goto, supra note 7, at 145-146; Miyajima Hideaki \& Nitta Keisuke, Kabushiki shoyū kōzō no tayōka to sono kiketsu - Kabushiki mochiai no kaishō / “fukkatsu” to kaigai tōshika no yakuwari (株式 所有構造の多様化とその帰結一株式持ち合いの解消・「復活」と海外投資家の役割)

[Diversification of Share-Ownership Structure and its Consequences / Unwinding and “Revival” of Cross-Shareholdings and the Role of Foreign Investors], in NIHON NO KIGYŌ TŌCHI (日本の企業統治) [CORPORATE GOVERNANCE IN JAPAN] 120-21 (Miyajima Hideaki ed., 2011) (Japan).

80. Goto, supra note 7, at 146; Tanaka Wataru, Kabushiki hoyū kōzō to kaisha-hō - “Bunsan hoyū no jojjō gaisha no jirenma” wo koete (株式保有構造と会社法一「分散保有の上場会社のジレンマ」 を越えて一) [Share-Ownership Structure and Corporate Law - Beyond the 'Dilemma of DispersedlyHeld Listed Corporations'], 2007 SHŌJI HōMU 30, 31-32 (2013) (Japan). For an in-depth case study of how stable-shareholdings influenced the outcome of the Bulldog Sauce case, see Xu Peng \& Tanaka Wataru, Baishū bōeisaku in za shadō obu kabushiki mochiai-jirei kenkyū (買収防衛策イン・ザ・シ ヤドー・オブ株式持ち合い一事例研究) [Takeover Defense in the Shadow of Cross-Shareholdings - A Case Study], 1885 SHōJı HōMu 4, 10-13 (2009) (Japan). 
takeovers, stable-shareholdings likely played a larger role in insulating Japanese listed companies from hostile takeovers than the general statistics reporting the decline of stable-shareholding for the TSE market as a whole suggest.

The third unique aspect of Japan's dispersed shareholder market, which is closely related to the decline in stable-shareholding, is the rapid rise of foreign shareholders. ${ }^{81}$ While this development has been widely noted, it is often misunderstood. As foreign shareholders have often been seen as a catalyst for hostile takeovers in Japan, the general rise in the percentage of foreign shareholders in TSE listed companies was seen as an indication that successful hostile takeovers would rise concurrently, especially since the rapid rise in foreign shareholders occurred at roughly the same time that stable-shareholdings decreased. Foreign ownership accounted for approximately 4.2 percent of market capitalization for TSE listed companies in 1990. By 2004, it had climbed to 22 percent and it now stands at 28 percent. ${ }^{82}$ Virtually all of these shares are held by foreign institutional investors, who have a history of actively engaging with management in their portfolio firms, suggesting that the increase in foreign ownership would be a catalyst for successful hostile takeovers. ${ }^{83}$

However, similar to the decline in stable-shareholdings, a more granular analysis of Japan's dispersed shareholder ownership landscape reveals a more complex picture. Empirical evidence confirms that foreign investors have preferred to invest in "larger corporations with higher ratios of overseas sales and higher return on assets." 84 This preference has dovetailed with the propensity of Japanese banks to sell their stable-shareholdings in larger firms. ${ }^{85}$ As such, the rise in foreign-shareholders appears to have accentuated the significant change in the type of dispersed shareholders at the largest listed companies in Japan (i.e., a movement away from dispersed stable-shareholders towards dispersed foreign-shareholders). At the same time, however, it has had a more limited impact on small and medium sized listed companies - which, as already highlighted above, tend to be the companies that are normally most vulnerable to hostile takeovers.

Obviously, the nature of Japan's shareholder landscape will continue to evolve. Currently, however, there is no indication that the shareholder market is becoming less dispersed, but there is some indication that there has been a limited revival of stable-shareholdings, especially in cash-rich companies that may be the target of hostile takeovers. ${ }^{86}$ There is also evidence that foreign institutional investors have changed their strategies for engaging with management of their

81. Milhaupt, supra note 4, at 2184.

82. TOKYO STOCK EXCHANGE, INC., supra note 67.

83. Milhaupt, supra note 4, at 2184.

84. Goto, supra note 7, at 146.

85. Id., at 145-146; Miyajima \& Nitta, supra note 79, at 135.

86. Goto, supra note 7, at 146; Miyajima \& Nitta, supra note 79, at 117-18, 125-31. 
portfolio firms in a way that better fits with Japan's unique lifetime employeecentered business culture ${ }^{87}$ (which is explained in detail in Part V below). Both of these trends suggest that the types of dispersed shareholders in Japan will continue to be less receptive to hostile takeovers than academics and market players familiar with hostile takeover markets in the United States and United Kingdom might expect. However, the significant changes in the nature of Japan's shareholder landscape over the last several decades suggest that things can change quickly and predictions about the future identity and behavior of Japan's dispersed shareholders - and how they will impact the evolution of Japan's market for hostile takeovers - should be made cautiously.

Finally, an important point that the evolution of Japan's shareholder landscape illuminates is that there are many "varieties of shareholders", which complicates the oversimplified dispersed versus concentrated shareholder dichotomy ${ }^{88}$ Each variety can have a unique and important impact on the development of a jurisdiction's market for hostile takeovers. Recognizing that there are varieties of dispersed shareholders is distinct from an earlier trend in the literature which suggested that, because a significant portion of TSE shares are held by stable-shareholders, Japan should be lumped into the monolithic category of jurisdictions with a concentrated shareholder landscape. ${ }^{89}$ Such a blunt classification is incorrect because it is incontrovertible-regardless of the empirical method used to measure the extent of dispersion - that Japan's stableshareholders are indeed widely dispersed. ${ }^{90}$ Also, the fact that Japan's stableshareholders have a common reason to support incumbent management does not eliminate their potential collective action problems or remove the empirical possibility of hostile takeovers.

The importance of recognizing Japan's stable-shareholders as a "variety" of dispersed shareholders (rather than as stereotypical controlling-block shareholders) is further illustrated by the fact that, as explained above, many sophisticated investors have attempted to test the stability of Japan's stableshareholders by launching hostile takeover bids-something that would obviously not happen if Japan's dispersed-stable-shareholders were stereotypical controlling-block-shareholders. This being said, as one of us has explained elsewhere, from another perspective it may be possible to view Japan's stableshareholders as on the continuum of "varieties of controlling shareholders"-but

87. See BUCHANAN ET AL., supra note 7, at 282-93 (discussing the disappearance of confrontational activism).

88. Ronald J. Gilson, Controlling Shareholders and Corporate Governance: Complicating the Comparative Taxonomy, 119 HARV. L. REV. 1641, 1652-59 (2006); Dan W. Puchniak, Multiple Faces of Shareholder Power, in RESEARCH HANDBOOK ON SHAREHOLDER POWER 523-24 (Jennifer G. Hill \& Randall S. Thomas eds., 2015).

89. Puchniak, supra note 16, at 42.

90. La Porta et al., supra note 2, at 471; see also Franks et al., supra note 2, at 2580. 
this view relies on an understanding of the diverse varieties of controlling shareholders, which has been largely overlooked in the literature. ${ }^{91}$

Although in the past leading academics incorrectly classified Japan as a stereotypical concentrated shareholding market, ${ }^{92}$ recent developments in comparative corporate law research suggest that the rationale for such a classification is becoming outdated. There is a growing recognition that there are "varieties of shareholders", and that these varieties may have a significant impact on the market for hostile takeovers and corporate governance more generally. ${ }^{93}$ In this vein, although the evolution of stable-shareholding and foreignshareholding make Japan's hostile takeovers market unique, having varieties of dispersed/concentrated shareholders does not appear to be unique to Japan. In addition, it appears that the need to understand the distinct varieties of shareholders in order to properly understand a jurisdiction's hostile takeovers market is something that is probably necessary in all jurisdictions.

\section{PART IV: THE MYOPIA OF THE ANGLO-AMERICAN LENS: UNDERSTANDING JAPAN’S REGULATORY FRAMEWORK ON ITS OWN TERMS}

The regulatory framework for hostile takeovers in Japan is often understood through an Anglo-American lens. ${ }^{94}$ Leading scholars and practitioners regularly highlight the fact that aspects of Japan's hostile takeovers regime were modelled on the United Kingdom's City Code in $1990^{95}$ and Delaware law in 2005. ${ }^{96}$ However, while acknowledging the historical origins of Japan's hostile takeover regime, Japanese academics tend to emphasize that Japan's regime differs substantially from its counterparts in the United Kingdom and United States. ${ }^{97}$

91. Puchniak, supra note 88, at 514.

92. Ronald J. Gilson \& Mark J. Roe, Understanding the Japanese Keiretsu: Overlaps Between Corporate Governance and Industrial Organization, 102 YALE L.J. 871, 875 (1993); Mark J. Roe, Some Differences in Corporate Structure in Germany, Japan and the United States, 102 YALE L.J. 1927, 1939 (1993); Mark D. West, The Pricing of Shareholder Derivative Actions in Japan and the United States, 88 NW. U. L. REV. 1436 (1994); Puchniak, supra note 16, at 41-42.

93. For example, it is now clear in the literature that institutional shareholders in the United States, which typically hold less than 5 percent of their portfolio companies, are normally rationally apathetic and support incumbent management. However, there is no suggestion that this feature of the dispersed shareholder market in the United States makes it a concentrated shareholder market. Conversely, there is an increasing realization that understanding the unique varieties of dispersed shareholders is critical for an understanding of how shareholder activism has evolved in the United States. Ronald J. Gilson \& Jeffrey N. Gordon, The Agency Costs of Agency Capitalism: Activist Investors and the Revaluation of Governance Rights, 113 CoLUM. L. REV. 863 (2013).

94. See, e.g., Gilson, supra note 6; Milhaupt, supra note 4; Armour et al., supra note 1.

95. Milhaupt \& West, supra note 3, at 19-20; Milhaupt, supra note 4, at 2205-2206; Armour et al., supra note 1, at 249-250. Even one of the authors was guilty of this. See Puchniak, supra note 4, at 20506.

96. Armour et al., supra note 1, at 250-253; Milhaupt, supra note 4, at 2205-2206; MASATSUGU SUZUKI, JAPAN: TAKEOVER GUIDE 2 (2014).

97. Eiji Takahashi, Japanese Corporate Groups Under the New Legislation, 3 EUR. Co. \& FIN. L. REV. 287, 298 (2006); see also Tomotaka Fujita, The Takeover Regulation in Japan: Peculiar Developments in the Mandatory Offer Rule, 3 U. TOKYO SOFT L. REV. 24 (2011). While leading corporate 
We suggest that viewing Japan's hostile takeovers regime through an AngloAmerican lens often results in myopia. Such an approach over-emphasizes the role played in Japan by mechanisms which have played a predominant role in the United States or United Kingdom (e.g., the poison pill, independent directors, directors' duties, and the mandatory bid rule). In a similar vein, explaining features of Japan's regulatory regime using terminology originally created to describe important features in the United States or United Kingdom (e.g., the "Japanese poison pill", "Japanese independent directors", and "Japanese mandatory bid rule") often results in Japan's regulatory regime being misunderstood. ${ }^{98}$

Ultimately, by highlighting how Japan's hostile takeovers regime must be understood on its own terms, this part of the article reveals that Japan's regulatory regime has charted its own course - but in a way that has been slow to develop and left many critical questions unanswered. ${ }^{99}$ For example, it is still unclear, under Japanese law, what types of defensive measures are legally permissible, ${ }^{100}$ how directors' duties apply in hostile takeover cases, ${ }^{101}$ and whether independent directors have any role to play in hostile takeovers. ${ }^{102}$

We posit that such critical questions have remained unanswered in Japan because other non-legal factors described in this Article (i.e., stableshareholdings and Japanese corporate culture) have effectively shielded the vast majority of listed companies from hostile takeovers. As a consequence, Japan's regulatory regime has not experienced a consistent flow of hostile takeover

law academics such as Aronson, Jacobs, Milhaupt, and West have provided a fairly nuanced description of Japanese law, such descriptions are often made through an Anglo-American lens. One of the authors, for example, even previously analyzed Japan's hostile takeover regime using Anglo-American devices (e.g. "poison pill”) as a basis for comparison. See Puchniak, supra note 4.

98. See, e.g., Eric Pfanner, Corporate Japan Looks for Outside Advice, WALL STREeT J. (Jun. 8, 2015), https://www.wsj.com/articles/corporate-japan-looks-for-outside-advice-1433789544; Yuko Takeo \& Nao Sano, Poison Pills Linger as Japan Firms Snub Abe Governance Push, BLOOMBERG (Jul. 28, 2015), https://www.bloomberg.com/news/articles/2015-07-28/poison-pills-linger-as-japan-firmsundercut-abe-governance-push.

99. Armour et al., supra note 1, at 258, 272; Stephen Givens, Looking Through the Wrong End of the Telescope: The Japanese Judicial Response to Steel Partners, Murakami, and Horie, 88 WASH. U. L. REV. 1571, 1572 (2011); Hideki Kanda, Corporate Governance in Japanese Law: Recent Issues and Trends, 11 Hastings BUS. L.J. 68, 71 (2015).

100. Armour et al., supra note 1, at 255; Tomotaka Fujita, Case No. 29: Corporate Law - Takeovers - Issuance of Share Options as Defence Measure - Principal Purpose Rule, in BUSINESS LAW IN JAPAN: CASES AND COMMENTS 313-22 (Moritz Bälz et al. eds., 2012) [hereinafter Business LAW IN JAPAN]; Hiroshi Oda, Case No. 30: Corporate Law - Takeovers - Defensive Measures - Equality of Shareholders, in BUSINESS LAW IN JAPAN, Id., at 327-30.

101. J. MARK RAMSEYER \& MASAKAZU IWAKURA, CASEBOOK M\&A - HARVARD LAW SCHOOL DE NO KŌGI WO MOTO NI (ケースブックM\&A ハーバード・ロースクールでの講義を基に) [CASEBOOK ON M\&A-BASEd ON LeCTURES AT HARVARD LAW SCHOOL] 87-93 (Shōji Hōmu 2015) (Japan).

102. Hiroyuki Watanabe, Designing a New Takeover Regime for Japan: Suggestions from the European Takeover Rules, 30 J. JAPAN. L. 89, 90-91 (2010). 
cases, ${ }^{103}$ which has prevented it from developing a similar level of detail and clarity in the law as compared to the United States. ${ }^{104}$ We suggest that this ambiguity has spawned uncertainty in the market, which in turn has created an additional barrier for the development of a vibrant hostile takeovers market in Japan. ${ }^{105}$

\section{Japan's foundational hostile takeovers regime-not the UK model}

In 1990, Japan's Securities and Exchange Act underwent a major revision which aimed to provide a more detailed regulatory framework for hostile takeovers. ${ }^{106}$ Japanese legislators claimed to draw on the United Kingdom's City Code for aspects of this revision. ${ }^{107}$ As such, it is understandable why leading comparative corporate law experts sometimes claim that Japan's post-1990 hostile takeovers regime adopted facets of the City Code model. ${ }^{108}$ For at least three reasons, this suggestion is incorrect and has resulted in a number of fundamental misunderstandings about the core features of Japan's post-1990 hostile takeovers regime.

First, contrary to the views of leading experts, Japan's post-1990 regulatory regime did not impose a mandatory bid rule-as it is understood in the United Kingdom - on acquirers seeking to purchase more than one-third of the shares in a listed company. ${ }^{109}$ Japanese acquirers are required to make an offer to all shareholders if they intend to acquire more than one-third of a listed company's

103. Milhaupt, supra note 4, at 2192-93 (observing that "sparse litigation” meant that Japan did not have "a particularly complete or instructive body of takeover jurisprudence" in the mid-2000s); Armour et al., supra note 1 , at 250.

104. Armour et al., supra note 1, at 263.

105. Even if the law were clarified so that management could "just say no" to a takeover bid (similar to under Delaware law) this might allow potential bidders and shareholder activists to develop strategies to have management remove defensive measures, as has happened in the United States with the poison pill and staggered boards. In Japan, however, it seems that the law is generally pro-management, but the fact that it is uncertain makes it difficult for bidders and/or shareholder activists to lobby to change the pro-management law because it is uncertain exactly what the law is - other than that it is generally promanagement.

106. Act Amending the Securities and Exchange Act (1990); Fujita, supra note 97, at 25.

107. Naitō Jun'ichi, Kabushiki kōkai kaitsuke seido no kaisei (株式公開買付制度の改正) [Reform of the Takeover Bids Regime], 1208 SHōJI HōMU 2 (1990) (Japan).

108. Milhaupt, supra note 4, at 2205; Milhaupt \& West, supra note 3, at 19-20.

109. Milhaupt \& West, supra note 3, at 19-20; Armour et al., supra note 1, at 249. 
shares ${ }^{110}$ through an off-market purchase. ${ }^{111}$ Acquirers, however, can cap the total percentage of shares they want to purchase for such offers as long as the cap is set below two-thirds of the target's shares. ${ }^{112}$ If, however, an offer for less than two-thirds of the target's shares is over-subscribed (i.e., the percentage of shares offered exceeds the acquirer's prescribed cap) then the acquirer must purchase the shares offered on a pro-rata basis up to the level of the cap, but importantly, is not required to purchase any shares beyond the cap. ${ }^{113}$

This is precisely the opposite of a United Kingdom-style mandatory bid rule, which prohibits setting a cap on the amount of shares the acquirer must purchase if the acquirer seeks to purchase more than 30 percent of the target's shares. ${ }^{114}$ The inability of an acquirer, after crossing a certain ownership threshold, to cap the percentage of shares purchased goes to the core of the United Kingdom's mandatory bid rule. Critically, this core feature is missing from Japan's one-third "mandatory bid rule". ${ }^{115}$

Japan's Securities and Exchange Act was amended in 2006 to implement another rule (which is still in effect) that requires an acquirer who aims to purchase more than two-thirds of a target company's shares to make an offer to all remaining shareholders, without allowing a cap on the percentage of shares to be acquired. ${ }^{116}$ This rule comports with the understanding of what a mandatory bid rule means in the United Kingdom (and most other jurisdictions). However, the policy rationale underlying Japan's two-thirds mandatory bid rule and its functional effect on the market for hostile takeovers are fundamentally different than under the United Kingdom's 30 percent mandatory bid rule (and mandatory bid rules in most other jurisdictions). ${ }^{117}$

110. Kin’yū Shōhin Torihiki-hō (金融商品取引法) [Financial Instruments and Exchange Act ("FIEA")], Act No. 25 of 1948 (Japan) [hereinafter FIEA], art. 27-2(1)(ii). It should be noted that an acquirer is also required to make an offer where he ends up holding 5 percent or more of the company's shares through an off-market purchase ("the 5 percent rule"), unless he has purchased his shares from 10 or fewer shareholders within 61 days (60 days plus the day of the purchase) and his resulting shareholding is one-third or less. FIEA, art. 27-2(1)(i), read with Kin'yū Shōhin Torihiki-hō Shikō-rei (金融商品取引 法施行令) [Financial Instruments and Exchange Act Enforcement Order], Cabinet Order No. 321 of 1965 (Japan) [hereinafter FIEA Enforcement Order], art. 6-2(3). This " 5 percent rule” is modeled after the United States Securities and Exchange Act of 1934. See Takahashi, supra note 97, at 298.

111. It is unlikely that on-market purchases will trigger the mandatory bid requirements in the Securities and Exchange Act or the FIEA. See FIEA, art. 27-2(1)(i)-(ii).

112. FIEA, art. 27-13(4), read with FIEA Enforcement Order, art. 14-2-2.

113. FIEA, art. 27-13(5).

114. The Panel on Takeovers \& Mergers, City Code on TaKeovers and Mergers 1968 (U.K.), http://www.thetakeoverpanel.org.uk/wp-content/uploads/2008/11/code.pdf?v=8Jan2018 [hereinafter CITY CODE], r. 9.1.

115. Japan allows acquirers to set a cap on the number of shares to be acquired. See FIEA, art. 2713(4)-(5), read with FIEA Enforcement Order, art. 14-2-2.

116. FIEA, art. 27-2(5), read with FIEA Enforcement Order, art. 8(5)(iii).

117. KRAAKMAN ET AL., supra note 10, at 252-55. For examples from other jurisdictions, see Umakanth Varottil, The Nature of the Market for Corporate Control in India, in COMPARATIVE TAKEOVER Regulation, supra note 56. See also Claire Te-Fang Chu, Takeover Laws and Practices in Taiwan: Recent Developments and Future Prospects, in COMPARATIVE TAKEOVER REGULATION, supra note 56; Donald, supra note 56. 
In the United Kingdom, the 30 percent mandatory bid rule is designed to prevent an acquirer, who obtains control of a target company, from using her control to extract private benefits from the target company. ${ }^{118}$ This is achieved by requiring a bidder who wants to gain control of a company (which, in the United Kingdom, is assumed to occur when a shareholder owns more than 30 percent of a company's shares) ${ }^{119}$ to offer to purchase all of the shares in the target company without setting a cap. In contrast, Japan's two-thirds "mandatory bid rule" explicitly allows an acquirer to gain de facto control (and even actual majority voting control) of a target company without making a United Kingdomstyle mandatory bid.

This difference is critical because it allows an acquirer to succeed in taking control of a target company through a hostile takeover bid without having to incur the cost of making a United Kingdom-style mandatory bid. ${ }^{120}$ In this limited respect, Japan's post-1990 regulatory regime is more similar to that of the United States than the United Kingdom because, in both jurisdictions, a hostile acquirer can gain control of a company through a hostile takeover bid without being required to make a United Kingdom-style mandatory bid. However, as suggested above, the Japanese and American regimes are distinct in that an acquirer in Japan must make a United Kingdom-style mandatory bid if they want to acquire more than two-thirds of the target company's shares-which is not required in the United States. ${ }^{121}$

In addition, the fundamental logic which underlies Japan's two-thirds mandatory bid rule is clearly distinct from the 30 percent mandatory bid rule in the United Kingdom. In the United Kingdom, the justification for setting the trigger for the mandatory bid rule at 30 percent is rooted in a market-based approach; due to the dispersed shareholding environment, 30 percent ownership of a listed company is assumed to normally provide an acquirer with de facto control. ${ }^{122}$ In contrast, the justification for setting the trigger for the mandatory bid rule at two-thirds in Japan is rooted in a law-based approach; according to

118. Private benefits of control have been defined as "the disproportionate returns. . . that dominant shareholders receive, often at the expense of minority shareholders. These benefits are impounded in the control premia charged for controlling blocks and in the price differentials that obtain between publicly traded high- and low-vote shares in the same companies.” See KRAAKMAN ET AL., supra note 10, at 8990 .

119. The City Code defines "control” as "an interest, or interests, in shares carrying in aggregate $30 \%$ or more of the voting rights (as defined below) of a company, irrespective of whether such interest or interests give de facto control.” See CITY CODE, “Definitions.” For more information on the City Code regime for takeovers in a comparative perspective, see generally Harald Baum, Takeover Law in the EU and Germany: Comparative Analysis of a Regulatory Model, 3 U. TOKYO J. L. \& POL'Y 60 (2006).

120. A shareholder with a simple majority $(50$ percent +1$)$ of the company's shares can generally control the election and removal of directors - and therefore the management of the company. See Goto, supra note 7, at 131-33; Kaisha-hō (会社法) [Companies Act], Act No. 86 of 2005 (Japan), arts. 339(1), 341.

121. KRAAKMAN ET AL., supra note 10, at 253-55.

122. John Armour \& David A. Skeel, Who Writes the Rules for Hostile Takeovers, and Why?: The Peculiar Divergence of U.S. and U.K. Takeover Regulation, 95 GEO. L.J. 1727, 1737 (2007). 
Japanese company law, a two-thirds shareholder vote is required to make fundamental corporate decisions. ${ }^{123}$ In contrast to both the United Kingdom and Japan, the United States has no mandatory bid rule because, by allowing the target company's board to use defensive measures to negotiate on behalf of the shareholders, there is no need to force the acquirer to purchase any shares at all. ${ }^{124}$

The second feature of Japan's post-1990 regulatory regime, which makes it incorrect to suggest that it generally followed the United Kingdom's City Code, is that Japanese courts were, and still are, at the center of the regime. ${ }^{125}$ In fact, the central role of the courts in regulating hostile takeovers in Japan preceded the 1990 revision to the Securities and Exchange Act. ${ }^{126}$ This is diametrically opposed to the approach taken in the City Code, which intentionally side-lines the courts and places The Panel on Takeovers and Mergers (the "Panel") at the center of the regulation of hostile takeovers in the United Kingdom. ${ }^{127}$

Although courts were (and still are) at the center of Japan's post-1990 regulatory regime, as suggested above, the relatively sparse nature of Japanese jurisprudence on hostile takeovers has left many critically important questions unanswered. ${ }^{128}$ Even though Japanese courts have sporadically rendered decisions on disputes involving hostile takeover attempts since the 1980s, the depth, detail, and clarity of Japan's hostile takeovers jurisprudence pales in comparison to the jurisprudence in Delaware over the same period. ${ }^{129}$ In this respect, the role of Japanese courts in the post-1990 regulatory regime is distinct from the role of courts in both the United Kingdom and United States.

The third feature of Japan's post-1990 regulatory regime, which makes it incorrect to suggest that it generally followed the City Code, is the informal role that target management was permitted to play in "frustrating" hostile takeover attempts until further changes to Japan's hostile takeover regime were made in the mid-2000s. ${ }^{130}$ During this period, a handful of hostile takeover cases reached

123. KANZAKI KATSURŌ ET AL., KINYŪ SHŌHIN TORIHIKI HŌ (金融商品取引法) [FINANCIAL INSTRUMENTS AND EXCHANGE ACT] 503 n.2 (2012) (Japan).

124. KRAAKMAN ET AL., supra note 10, at 253-55.

125. Armour et al., supra note 1, at 263-65.

126. Notably, the Chujitsuya and Inageya case, Tōkyō Chihō Saibansho [Tokyo Dist. Ct.] Jul. 25, 1989, 704 HANREI TAIMUZU [HANTA] 84 (Japan).

127. Armour \& Skeel, supra note 122, at 1744-45; Armour et al., supra note 1, at 262-63.

128. Armour et al., supra note 1, at 258, 272; Givens, supra note 99, at 1571-72; Kanda, supra note 99 , at 71 .

129. Givens, supra note 99 , at 1581.

130. It should be noted that, although Japan's post-war history of unsuccessful hostile takeover attempts can be traced back to the 1970s, "every year from the late 1970s until the burst of the bubble in the late 1980s, there were several major share acquisitions of large listed Japanese companies by maverick Japanese investors with hostile intents.” Every hostile share acquisition in this period ultimately failed to remove control from incumbent management, but many ended "successfully" for the acquirers as they "greenmailed" management of the target companies into having the target companies repurchase the shares they acquired at a premium in order to maintain their control. The defensive tactic to payoff greenmailers went almost entirely unchallenged by general shareholders, likely because it would have 
Japanese courts. Generally, in these cases, the target company's lifetime employee dominated board would respond to a hostile takeover attempt by issuing the target company's shares to a friendly stable-shareholder ${ }^{131}$ — which under Japanese company law could be done without shareholder approval. ${ }^{132}$ In several of these cases, the hostile bidder responded to this defensive measure by seeking an interim injunction under the Commercial Code on the basis that such an issuance of shares was "extremely unfair". ${ }^{133}$ Through these cases, the Japanese courts developed a judicial doctrine, the "primary purpose rule," to determine whether such an issuance of shares was "extremely unfair". ${ }^{134}$ According to the "primary purpose rule" the issuance of shares would not be "extremely unfair" if the primary purpose of the issuance was to raise capital rather than to maintain control of the target company. ${ }^{135}$

Some leading comparative corporate law scholars have noted that Japan's "primary purpose rule" appears to be doctrinally similar to the common law directors' duty in the United Kingdom which requires directors to exercise their power to issue shares only when it is for the "proper purpose" of raising capital (and not defeating a hostile takeover bid). ${ }^{136}$ In addition, on its face, Japan's "primary purpose rule" appears to dovetail with the United Kingdom's "no frustration rule" which prohibits the target company's board from taking any action to frustrate a takeover offer without shareholder approval. ${ }^{137}$ However, in its application from the 1980s until 2005, Japan's "primary purpose rule” could

been contrary to the interest of stable shareholders to act and because directors' duties as well as derivative actions remained grossly underdeveloped at that time. See Puchniak, supra note 4, at 234.

131. See, e.g., Tokyo Dist. Ct. Jul. 25, 1989, 704 HANTA 84.

132. Prior to the 2005 revision, the Commercial Code permitted the board of directors to issue shares or share options, unless the conditions of such issuance were "particularly favourable" to its subscribers. SHŌHŌ

(商法)

[COMMERCiAl CoDE], Act No. 48 of 1899 (Japan) [hereinafter COMMERCIAL CoDE], arts. 280-2(1)-(2), 280-20(2), \& 280-21(1) (repealed).

133. COMMERCIAL CODE, arts. 280-10, 280-39(4) (repealed).

134. For an exhaustive treatment of the jurisprudence in Japanese, see Matsunaka Manabu, Shuyo mokuteki ruuru no kentō (ichi) (主要目的ルールの検討 (一) ) [The Primary Purpose Rule (Part 1)], 57 HANDAI HŌGAKU 1011 (2008) (Japan).

135. The jurisprudence is legion, but an early and influential case is the Chujitsuya and Inageya case. See Tokyo Dist. Ct.] Jul. 25, 1989, 704 HanTA 84; see also Mitsuhiro Kamiya \& Tokutaka Ito, Corporate Governance at the Coalface: Comparing Japan's Complex Case Law on Hostile Takeovers and Defensive Measures, in CORPORATE GOVERNANCE IN THE 21ST CENTURY: JAPAN's GRADUAL TRANSFORMATION 183 (Luke Nottage et al. eds., 2008); HIROSHI ODA, JAPANESE LAW 265 (3d ed. 2009); Givens, supra note 99, 1574-75; Fujita, supra note 100, at 313-22; Oda, supra note 100, at 323-30.

136. Armour et al., supra note 1, at 250 n.147. The leading case in the United Kingdom on the "proper purposes" duty prior to its codification in section 171 of the Companies Act of 2006 (UK) was Howard Smith Ltd. v. Ampol Petroleum Ltd. [1974] AC 821 (PC) (appeal taken from New South Wales). For the present post-codification position, see Eclairs Group Ltd. v. JKX Oil \& Gas Plc. [2015] Bus. L.R. 1395 (UKSC) (appeal taken from Eng. \& Wales)

137. The "no frustration rule" provides that "during the course of an offer, or even before the date of the offer if the board of the offeree company has reason to believe that a bona fide offer might be imminent, the board must not, without the approval of the shareholders in general meeting, take any action which may result in any offer or bona fide possible offer being frustrated or in shareholders being denied the opportunity to decide on its merits. . ..” See CITY CODE, r. 21.1. 
not be any more different than the United Kingdom's "no frustration rule" and "proper purpose" duty for at least two reasons. ${ }^{138}$

First, it is widely recognized that Japanese courts were inclined to uphold the target board's decision to issue shares to a friendly stable-shareholder in the context of an ongoing takeover bid as long as the target board referred to some need to raise capital-which was normally easy to do. ${ }^{139}$ Although never explicitly stated by the court, the general consensus among leading authorities was that in cases where the court had a reason to believe that the hostile acquirer was a greenmailer, courts were inclined to set an extremely low bar for finding that there was a capital raising purpose for issuing shares. ${ }^{140}$ Therefore, in practice, Japanese case law, as sparse as it was, appeared to allow management to effectively frustrate hostile takeover bids, without shareholder approval, when it appeared that management was acting in the best interests of the company. This approach is diametrically opposed to the United Kingdom's "no frustration rule" and "directors' duty to act for a proper purpose" in the context of a hostile takeover. ${ }^{141}$

Second, the "primary purpose rule" applies to the issuance of shares, but it is unclear if it has any applicability to other defensive measures that target boards may take to frustrate a takeover bid. ${ }^{142}$ As such, from the 1980s until 2005, substantial uncertainty concerning the legality of many other defensive measures significantly distinguished Japan's hostile takeovers regime from the United Kingdom's regime, which provides a general "no frustration rule". ${ }^{143}$ In addition, Japan's "primary purpose rule" was also distinct from Delaware's general position on the ability of a target board to frustrate a hostile takeover attempt, which provides clear guidelines for target management to "just say no" when proper procedures are followed. ${ }^{144}$

138. See generally Yamanaka Toshiaki, Seitō mokuteki ruuru ni yoru torishimariyaku ni taisuru kiritsu: eikoku 2006 kaisha-ho wo fumaete (正当目的ルールによる取締役に対する規律一一 英国 2006 年会社法を踏まえて) [Monitoring Directors with the Proper Purpose Test: Lessons from the UK Companies Act 2006] (Kinyū shōjihō [Fin. \& Comm. Law] Working Paper, http://www.securities.j.utokyo.ac.jp/w-papers/2014-9_Yamanaka.pdf (last visited Aug. 19, 2016) (Japan).

139. A leading Japanese academic has observed that "the courts have recognized 'finance' as being the principal purpose very easily in the past. Some courts, when finding the principle to be 'finance' rather than 'control', relied on the simple fact that there was a need for external funds. Others referred to the reason why equity finance was desirable compared with other methods of finance or why public offering does not achieve the purpose in the case. . . " See Fujita, supra note 100, at 317-18 (footnotes omitted).

140. Oda, supra note 100, at 327.

141. The United Kingdom Supreme Court recently confirmed that a director cannot rely on the company's best interests to defend herself against alleged breaches of the "proper purpose" duty. See Eclairs Group Ltd. v. JKX Oil \& Gas Plc [2015] Bus. L.R. 1395 (UKSC) (UK); Hans Tjio, The Proper Purpose Rule, [2016] LlOYD’s MAR. \& COMM. L.Q. 176, 185 (2016).

142. Oda, supra note 100 , at 327.

143. Armour et al., supra note 1, at 255.

144. KRAAKMAN ET AL., supra note 10, at 238-39. Further, given that the poison pill in Japan was generally viewed as being technically impossible and illegal under Japanese law until an amendment to the Commercial Code in 2001 (and even after this, as explained below, its legality is still uncertain), 
In sum, it is incorrect to suggest that Japan's post-1990 to 2005 regulatory regime even loosely followed the United Kingdom's City Code model. As shown, in many respects, Japan's approach to regulating hostile takeovers was the polar opposite of the United Kingdom's approach. Moreover, during this period, as we have shown, Japan's approach was also significantly different from Delaware's.

\section{Japan's post-2005 hostile takeovers regime-not the next Delaware ${ }^{145}$}

There were great expectations among academics, pundits, and investors that 2005 would be the year of watershed change for the success of hostile takeovers in Japan. These expectations were brought to life by Livedoor's audacious hostile takeover bid for Nippon Broadcasting System (NBS). ${ }^{146}$ Livedoor's founder and president, Takafumi Horie, was a brash, 32-year-old Tokyo University dropout who made his mark as a dotcom billionaire-cum-corporate raider. With his spikyhair, "Cheshire cat" grin, t-shirt and jeans business attire, and penchant for bikiniclad girls and Ferraris, Horie became a cultural icon for his attempt to change Japan's traditional, lifetime employee centered corporate culture. ${ }^{147}$

In early-February 2005, using a loophole in the Securities and Exchange Act, Livedoor surreptitiously acquired 29.6 percent of NBS' shares in after-hours trading (bringing its stake up to 38 percent) and shocked the market by announcing its intention to make a takeover bid for NBS. ${ }^{148}$ NBS responded quickly by announcing that it would issue warrants to a friendly stableshareholder as a defensive measure, which, if exercised, would have dramatically increased NBS' share capital by 140 percent and diluted Livedoor's stake in NBS to less than 20 percent. ${ }^{149}$

In response to NBS' defensive measure, Livedoor sought an injunction from the Tokyo District Court to stop the issuance of the NBS warrants. The fact that the warrants, if exercised, would have more than doubled NBS' capital made it practically impossible for NBS to argue that the "primary purpose" of the issuance was to raise capital and not to entrench management. ${ }^{150}$ As such, NBS "never denied that the new share issue was intended to dilute the shares of Livedoor." ${ }^{151}$ Therefore, unsurprisingly, in light of the well-established "primary purpose rule", the Tokyo District Court granted the injunction

management's ability to frustrate hostile bids in Japan differs significantly from management's ability to do so in the United States.

145. Some material in this section has been reproduced from Puchniak, supra note 4. The authors are grateful to the Berkeley Business Law Journal for its permission to do so.

146. Armour et al., supra note 1, at 250.

147. Puchniak, supra note 4, at 246.

148. Fujita, supra note 100, at 314.

149. Puchniak, supra note 4, at 245.

150. Id.

151. Oda, supra note 100 , at 327. 
preventing NBS from issuing the warrants, which was affirmed on appeal by the Tokyo High Court. ${ }^{152}$

Horie's aggressive takeover bid and successes in court led many experts and leading academics to posit that Livedoor's bid for NBS marked the "advent of an era of hostile takeovers" in Japan. ${ }^{153}$ Noted pundits claimed that Livedoor's takeover attempt sparked "a revolution in [Japan's market for] corporate control." 154 Influential policymakers even erroneously credited Horie with pulling off Japan's first-ever successful hostile takeover before the Livedoor bid was even complete. ${ }^{155}$

In the end, however, all such predictions were proven wrong. In response to Livedoor's court victories, NBS' largest friendly stable-shareholder increased its NBS holdings and another friendly shareholder "borrowed" a large portion of shares that NBS held in Fuji TV-the "crown jewel" of NBS and the primary reason that Horie wanted to take over the company. In addition, NBS' management received crucial support from its lifetime employees. 90 percent of them signed a public statement supporting NBS' incumbent management over Horie and Livedoor. ${ }^{156}$

In April 2005, in an act that was tantamount to admitting defeat, Livedoor sold its significant block of NBS shares to NBS' largest stable-shareholder at a marginal profit, which was just enough to allow Horie to "save face". ${ }^{157}$ In the end, Livedoor was defeated because, in traditional fashion, friendly stableshareholders rallied around incumbent management, "demonstrating that the era of a truly free stock market [was] still a long way off." 158

There were some experts who, even in the wake of Livedoor's failure, continued to view Horie's failed hostile takeover attempt as a major shift in Japan's market for corporate control. ${ }^{159}$ In 2006, however, such views faded when Horie was arrested and indicted on allegations of accounting fraud and stock market manipulation. ${ }^{160}$ The scandal spurred a massive two-day sell-off on the TSE. The volume of selling was so great that the TSE was forced to close

152. Tōkyō Kōtō Saibansho [Tokyo High Ct.] Mar. 23, 2005, 1173 Hanrei TAimUZU [HANTA] 125 (Japan) [hereinafter Livedoor]; Puchniak, supra note 4, at 245; Fujita, supra note 100, at 314.

153. Puchniak, supra note 4, at 238.

154. ECONOMIST INTELLIGENCE UNIT, supra note 3, at 7.

155. Japan's highly regarded Corporate Value Study Group, which drafted a report that was foundational in establishing Japan's Takeover Guidelines, erroneously suggests in its report that Livedoor's hostile bid was successful. See Corporate VAlue STUDY Group, Corporate VALUE REPORT (2005),

http://www.meti.go.jp/policy/economy/keiei_innovation/keizaihousei/pdf/houkokusyo_hontai_eng.pdf.

156. Puchniak, supra note 4, at 245-46.

157. ECONOMIST INTELLIGENCE UNIT, supra note 3, at 11-13.

158. Id.

159. See Milhaupt, supra note 4, at 2203.

160. Keidanren Rues Livedoor Entry, JAPAN TIMES (Jan. 19, 2006), https://www.japantimes.co.jp/news/2006/01/19/business/keidanren-rues-livedoorentry/\#.Wn50bGaZMmU; Puchniak, supra note 4, at 259. 
early, a move that was seen as "a blow to the nation's pride." 161 This caused markets around the world to fall and was dubbed by the news media as the "Livedoor shock". Horie was disgraced and Livedoor's share price plummeted from 696 yen to 61 yen in one month. In April of that year, the stock was delisted from the TSE.

The picture of Horie solemnly bowing before a judge in a Tokyo courtroom, with his trademark spiky-hair cropped and wearing a conservative "salary man" black suit, was a stark contrast to the once renegade shareholder activist who was famous for flamboyantly challenging Japan's conservative business culture. In March 2007, Horie was sentenced to two and a half years in prison. Given that Japanese courts rarely impose jail terms for securities violations, many viewed this sentence as extremely harsh. ${ }^{162}$

In retrospect, the Livedoor bid clearly did not mark a watershed change for hostile takeovers in Japan. A decade later, it is now clear that predictions that Japan would quickly transform into something akin to Delaware as a result of the Livedoor bid have clearly not come to pass. However, the manner in which the Tokyo High Court applied the "primary purpose rule" in upholding the District Court's injunction to prevent NBS' issuance of warrants did create a noteworthy development in Japan's hostile takeovers jurisprudence. But again, these developments can only be properly understood when viewed through a Japanese lens.

As explained above, prior to the Livedoor case, the issuance of shares by the target's board could only be justified if it was proven that the "primary purpose" of the issuance was to raise capital, rather than to maintain control of the target company. Although in practice Japanese courts were often quick to accept explanations offered by the target as to why raising capital was required, (which in many cases was tantamount to allowing the target board to issue shares as a defensive measure) formally a target board could not claim that the "primary purpose" of a share issuance was to maintain corporate control—even if doing so was in the company's best interest. In short, prior to Livedoor, Japanese courts had not formally recognized any circumstances in which a target board could, without shareholder approval, take defensive measures. ${ }^{163}$

However, the Tokyo High Court in the Livedoor case explicitly recognized that in four limited circumstances a target company's board can issue shares or warrants for the "primary purpose" of maintaining control. These four circumstances occur when the hostile bidder is: ${ }^{164}$

161. James Brooke, After Panic, Tokyo Market Rebounds, N.Y. Times (Jan. 19, 2006), http://www.nytimes.com/2006/01/19/business/worldbusiness/after-panic-tokyo-market-rebounds.html.

162. Puchniak, supra note 4, at 259.

163. Oda, supra note 100, at 328-29.

164. Fujita, supra note 100, at 319. 
(1) acquiring the target's shares with the intent of requiring the corporation to buy them back at a higher price ('greenmail');

(2) temporarily taking control of the corporation and running the corporation in the interests of the acquirer at the expense of the corporation, such as acquiring the corporation's important assets at low prices;

(3) pledging assets of the company as collateral for debts of the acquirer or its group companies or using the company's funds to repay such debts; or

(4) temporarily taking control of the management of the company and selling valuable assets that are currently not related to the company's business and temporarily declaring high dividends with profits from the disposition, or selling the shares at a higher price after the share price rose, due to temporarily high dividends.

It seems clear that the High Court intended these four circumstances to create a filter that would allow wealth-enhancing hostile takeovers to proceed without interference from target boards, but still permit target boards to block wealthreducing hostile takeovers. The High Court's judgment generated considerable academic attention, especially in the United States, given its similarity to Delaware's Unocal rule "with its implicit threat analysis and proportionality requirement". ${ }^{165}$ In Japan, concerns have been expressed by leading academics that the four circumstances may in fact provide a formal justification for management to block wealth-enhancing hostile takeovers-particularly as the third circumstance could be interpreted to allow management to issue shares to prevent a wealth-enhancing leveraged buyout from succeeding. ${ }^{166}$

Although a decade has passed since the Livedoor decisions, no jurisprudence has developed to clarify the scope or application of the four circumstances. This lack of clarity has created uncertainty as to precisely when a target board can issue shares or warrants for the "primary purpose" of maintaining control without shareholder approval. We suggest that this lack of clarity is partially responsible for inhibiting a vibrant market for hostile takeovers in Japan.

In the midst of the Livedoor case, another significant development occurred in 2005 when the Legislative Council of the Ministry of Justice released the Final Report on the new Companies Act. ${ }^{167}$ The Final Report included proposed amendments to facilitate M\&A, which sparked fear in corporate Japan of an

165. Milhaupt, supra note 4, at 2194. Milhaupt argues that these similarities "may not be coincidental," given that the High Court had apparently been briefed on the prevailing approach under Delaware law, and the existence of a substantial body of academic commentary on the applicability of a Revlon or Unocal rule in the Japanese context.

166. Fujita, supra note 100 , at 319.

167. Legislative CounCIL OF THE Ministry OF JustiCE, KAISHA HŌSEI NO GENDAI-KA NI KANSURU YŌKŌ (会社法制の現代化に関する要綱) [REPORT ON THE MODERNIZATION OF THE CORPORATE LAW REGIME] (2005). 
increase in hostile takeover activity—especially by foreign acquirers. ${ }^{168}$ To alleviate this fear, the Japanese government released the Takeover Guidelines, which was a non-binding guide for companies that outlined the proper procedures for adopting defensive measures. The Takeover Guidelines made it clear that pre-bid defensive measures could be adopted by potential target companies, but that such measures should be endorsed in advance by shareholders. ${ }^{169}$

The legal relevance of the non-binding Takeover Guidelines has been significantly diminished ${ }^{170}$ by the fact that they are non-binding and have been largely superseded by two subsequent court decisions (discussed below) and subsequent revisions to the TSE listing rules that substantially incorporate the Takeover Guidelines. ${ }^{171}$ This being said, at the time the Takeover Guidelines were released, they appeared to inspire a handful of listed Japanese companies to adopt "Pre-warning Rights Plans" (PRPs) as a uniquely Japanese type of prebid defensive measure. ${ }^{172}$ After the TSE Revised Rules were implemented in January 2006, the number of Japanese listed companies that adopted PRPs increased at a more significant, but moderate, rate-peaking at 20.3 percent of TSE listed companies in 2011. ${ }^{173}$

PRPs have often been described as the Japanese "poison pill”-suggesting that the defensive measure commonly referred to in the United States as the "poison pill” has been transplanted to Japan. ${ }^{174}$ Describing PRPs as poison pills or suggesting that PRPs are modeled on the typical US-style poison pill ${ }^{175}$ is misleading for at least three reasons. First, the typical PRP merely involves a company's board issuing a press release-it does not involve amending the corporate constitution and it is not a legally binding document like a typical USstyle poison pill. ${ }^{176}$ The press release normally states that if a takeover bid is commenced, which may result in the bidder holding more than a certain amount of the target's shares (typically, 20 percent), then the target company will establish a special committee. Then, the special committee will determine

168. Fujita, supra note 100 , at 322.

169. See TAKEOVER GUIDELINES, supra note 4, at 5-6.

170. Oda, supra note 100 , at 329.

171. TOKYO STOCK EXCHANGE, INC., BAISHŪ BŌEISAKU NO DŌNYŪ NI KAKARU JŌJŌ SEIDO NO SEIBI TŌ NI TSUITE (買収防衛策の導入に係る上場制度の整備等について) [LISTING RULE REVISION WITH REgARDS TO THE ADOPTION OF TAKEOVER DEFENSIVE MEASURES] (2006), http://www.jpx.co.jp/files/tse/rules-participants/public-comment/data/060124jojo.pdf (Japan).

172. By 2006, less than 2 percent of Japan's listed companies had adopted such measures. Puchniak, supra note 4 , at 256 n.395.

173. TOKyo Stock Exchange, Inc., TSE-Listed Companies White PAPER on Corporate GOVERNANCE $2011 \quad$ (2011), http://www.jpx.co.jp/equities/listing/cg/tvdivq0000008jb0att/b7gje60000037hvl.pdf.

174. ENTERPRISE LAW: CONTRACTS, MARKETS AND LAWS IN THE US AND JAPAN 33 (Zenichi Shishido ed., 2014) [hereinafter ENTERPRISE LAW]; BUCHANAN ET AL., supra note 7, at 250.

175. Id.

176. Armour et al., supra note 1, at 254. 
whether it would be in the target company's best interest to issue warrants to shareholders other than the bidder as a defensive measure. ${ }^{177}$ Unlike the typical US-style poison pill, the non-legal and contingent nature of PRPs make it unclear what will occur if the acquirer "triggers" the PRP, and exactly how PRPs will operate in practice.

Second, it is uncertain whether a PRP is legally valid if it has not been approved by shareholders. This uncertainty does not exist with a US-style poison pill which can be approved in advance of a takeover bid solely by the board. ${ }^{178}$ Surprisingly Nireco, which took place two months after Livedoor in 2005, is the only case which has considered the legality of a PRP. ${ }^{179}$ In Nireco, the Tokyo High Court upheld the District Court's decision to grant an injunction to prevent a TSE listed company from putting a PRP in place. ${ }^{180}$

The decision in Nireco suggests that the standard applied by the High Court in the Livedoor decision-which allowed the board, without shareholder approval, to use a defensive measure during a takeover bid in the four circumstances described above-does not apply to pre-bid defensive measures. ${ }^{181}$ If this is the case, then possibly all PRPs must be approved by shareholders to be valid, which would make them fundamentally different than the typical US-style poison pill. However, some leading Japanese law professors are of the view that the Nireco case has little precedential value, because the PRP in Nireco was not a typical PRP as it was constructed so that if triggered it would not only discriminate against the acquirer, but also against another sub-group of 'innocent' shareholders. ${ }^{182}$ Therefore, it remains an open question whether PRPs must be approved by shareholders to be valid, creating a large amount of uncertainty and distinguishing PRPs from a typical US-style poison pill.

177. TOKYO STOCK EXCHANGE, INC., M\&A WO TORIMAKU GENJŌ NI KANSURU TŌSHIKA IKEN NO GAIYŌ: BAISHŪ BŌEISAKU WO CHŪSHIN NI (M\&A をとりまく現状に関する投資家意見の概要一買収 防衛策を中心に) [OUTLINE OF INVESTOR OPINIONS CONCERNING THE CURRENT SITUATION SURROUNDING M\&A: WITH FOCUS ON TAKEOVER DEFENSIVE MEASUREs] (2008), http://www.jpx.co.jp/equities/improvements/general/tvdivq0000004iib-att/2008ma.pdf (Japan); Armour et al., supra note 1 , at 254 n.175.

178. Moran v. Household Int'l, Inc., 500 A.2d 1346, 1351-53 (Del. 1985). US scholars have opined that pursuant to the general principles of shareholder ratification of interested transactions between the corporation and its managers, prior approval of the pill by a fully informed, disinterested majority would "cleanse the 'specter' of interested action in the takeover context." Neil Lieberman, Justice Jackson in the Boardroom: A Proposal for Judicial Treatment of Shareholder-Approved Poison Pills, 2008 CoLUM. Bus. L. REV. 360, 371-72 (2008).

179. Tōkyō Chihō Saibansho [Tokyo Dist. Ct.] Jun. 1, 2005, 1186 Hanrei TAIMUzu [Hanta] 274 (Japan); Tōkyō Chihō Saibansho [Tokyo Dist. Ct.] Jun. 9, 2005, 1186 Hanrei TAimuzu [HANTA] 265 (Japan); Tōkyō Kōtō Saibansho [Tokyo High Ct.] Jun. 15, 2005, 1186 HANREI TAIMUZU [HANTA] 254 [hereinafter Nireco].

180. Fujita, supra note 100, at 320.

181. Id.

182. Such "innocent" shareholders were defined as shareholders other than the acquirer. The Tokyo High Court further opined that, had the pills been more carefully designed, such that they would have avoided harming such shareholders, the outcome of the Nireco case might have turned out differently. See id. at 320 . 
Third, PRPs are distinct from US-style poison pills in that they were adopted (and still exist) in a corporate governance environment which has no history of successful hostile takeovers. When the poison pill was recognized as valid by courts in the United States it arguably shifted the balance of power from hostile acquirers to target boards, making the impact of the poison pill a significant event and causing acquirers and shareholder activists to search for ways to challenge and remove poison pills. As mentioned above, the fact that a decade after the adoption of PRPs by TSE-listed companies there has only been a single challenge in court to a PRP suggests that rather than a rebalancing of power, PRPs merely reinforced the existing Japanese post-war corporate governance norm: that stable shareholding and Japanese corporate culture place corporate control firmly in the hands of Japan's lifetime employee dominated boards—which has quelled the development of an active hostile takeovers market.

Finally, in 2007, for the first and only time the Supreme Court of Japan considered the validity of a defensive measure in the Bulldog Sauce case. ${ }^{183}$ This case involved a takeover bid by a US private equity fund for an iconic Japanese condiment producer named Bulldog Sauce. In response to the bid, Bulldog Sauce's board proposed taking the defensive measure of issuing three warrants per share to all existing shareholders, which were exercisable for shares by all shareholders except the bidders. However, if the warrants were exercised, then the bidders would be entitled to receive cash in lieu of shares, which at the time amounted to an $\$ 18.7$ million payment. This measure essentially provided compensation to the bidders for the discriminatory issuance of shares to the other shareholders.

Most importantly, as the bid was made shortly before Bulldog Sauce's annual general shareholders meeting, the board decided to put its proposed defensive measure before the shareholders for approval. ${ }^{184}$ Astoundingly, the proposed defensive measure was approved by 88.7 percent of a qualified majority of shareholders, which was almost all the shareholders aside from the bidder. Nevertheless, the bidder sought an interim injunction to prevent the warrant issuance-a strange turn of events considering that none of the shareholders appeared to be willing to sell their shares to the hostile acquirer. ${ }^{185}$

The Tokyo District Court denied the injunction and its decision was upheld by the Tokyo High Court and the Supreme Court of Japan. The Supreme Court reasoned that shareholders have the right to determine whether potential damage to the company would warrant taking defensive measures. Moreover, it held that the discriminatory treatment to the bidder as a shareholder was justifiable

183. Saikō Saibansho [Supt. Ct.] Aug. 7, 2007, 61 SAIKŌ SAIBAnSHO Minji HANREISHŪ [Minshū] 2215 (Japan) [hereinafter Bulldog Sauce]; Oda, supra note 100, at 323-30.

184. Oda, supra note 100 , at 324.

185. Id. 
because "fair and adequate measures" had been made to compensate the bidder for not being able to exercise its warrants for shares. ${ }^{186}$

Similar to Nireco, leading Japanese academics view Bulldog Sauce as having limited precedential value because it too involved unusual circumstances which make it easily distinguishable from the typical hostile takeover case. ${ }^{187}$ The fact that almost all of the target's shareholders supported the defensive measure begs the question of why the defensive measure was required in the first place. In addition, it is curious that the shareholders would support the defensive measure given the generous payment made to the bidder. We suggest below that this support can only be explained by understanding the combined effect of stable shareholders and Japanese business culture.

Ultimately, the idiosyncratic aspects of Bulldog Sauce left at least three important legal questions unanswered. First, the decision did not clarify whether the board has the power to implement defensive measures without shareholder approval because the shareholder approval for the defensive measure was so overwhelming in this case. ${ }^{188}$ Second, the decision does not clarify the legality of PRPs because this case involved a post-bid—not a pre-bid—defensive measure. Third, the decision raises the question of whether it is necessary to compensate the bidder for discriminatory treatment caused by the defensive measure in order for it to be considered "fair and reasonable" even if it is approved by shareholders. ${ }^{189}$

From a legal perspective, what has occurred in the decade following Livedoor's hostile takeover bid has been the opposite of the predictions that Japan would become something akin to Delaware. In the past decade, Japan's market for hostile takeovers has withered and legal developments have ossified. As described above, many of the most basic legal questions, which were quickly made relatively clear in the United Kingdom and United States, have been left impermissibly vague in Japan for over a decade.

Although we posit that this legal uncertainty has created a further barrier to the development of a vibrant market for hostile takeovers in Japan, it also appears that, in general, law has played a secondary role to stable shareholding and Japanese corporate culture in driving the evolution of Japan's hostile takeovers market. Ironically, even in Japan's two leading hostile takeover cases, Livedoor

186. Armour et al., supra note 1 , at 256; Oda, supra note 100, at 326.

187. Oda, supra note 100, at 329-30.

188. Id. at 329-30.

189. It is worth noting that, after Bulldog Sauce, the Corporate Value Study Group issued a nonbinding report that took the position that compensation of the bidder is unnecessary when the bidder does not follow the procedure stated in the company's PRP. See CORPORATE VALUE STUDY GROUP, TAKEOVER DEFENSE MEASURES IN Light OF RECENT ENVIRONMENTAL ChANGES (2008), http://www.meti.go.jp/english/report/data/080630TakeoverDefenseMeasures.pdf. However, as this report is non-binding, there is some uncertainty about how it will impact the future development of the law. 
and Bulldog Sauce, the extra-legal factors were far more important than the court decisions.

Specifically, despite the fact that the court enjoined the defensive measure in Livedoor, management ultimately prevailed as friendly stable-shareholders came to the rescue of the target company. In Bulldog Sauce, the almost unanimous support that management received from friendly and stable-shareholders ensured the entrenchment of management regardless of the law. Indeed, whether Bulldog Sauce took place in Japan, the United States, or the United Kingdom, with almost all shareholders supporting management, the result would have been the same. ${ }^{190}$ As such, as much as some corporate law professors like to believe that law matters most, as explained in the next section, it appears that Japan's unique business culture, combined with the impact of stable shareholding, may be more important than the law in limiting a vibrant market for hostile takeovers in Japan.

\section{PART V: THE IMPORTANCE OF JAPAN'S UNIQUE CORPORATE CULTURE: A FORMIDABLE BARRIER TO HOSTILE TAKEOVERS}

Traditionally, Japanese culture has been considered to be a significant barrier to hostile takeovers. ${ }^{191}$ More recently, however, it has been suggested that this cultural barrier to hostile takeovers has been substantially eroded. We suggest that these more recent claims are overstated. Indeed, we posit that an understanding of Japan's unique corporate culture is essential to understand why a vibrant hostile takeovers market has not developed in Japan.

Historically, almost every analysis of the lack of hostile takeovers in Japan mentioned the "cultural distaste" that the Japanese had for the sale of a company and the "taboo" associated with hostile takeovers. ${ }^{192}$ Japanese managers have often been seen to possess a sense of "corporate paternalism" toward employees, which made it shameful to allow their "family" to be the victim of a hostile takeover. ${ }^{193}$ The concept that Japanese corporations are more like families than profit machines, has traditionally provided an additional rationale for stableshareholders to protect each other from hostile takeovers and reinforced the rationale provided above that stable-shareholders often reject bids with substantial premiums to maintain long-term business relationships.

The foundation of Japan's post-war corporate culture has been linked to the fact that almost all large listed companies recruit their core employees from top Japanese universities and provide them an implicit promise of a job until

190. The defensive measure was approved by around 88.7 percent of the votes present and 83.4 percent of all votes. See Oda, supra note 100, at 325.

191. Curtis J. Milhaupt, Creative Norm Destruction: The Evolution of Nonlegal Rules in Japanese Corporate Governance, 149 U. PA. L. REV. 2083, 2090-91 (2001); Puchniak, supra note 4, at 226-228.

192. Milhaupt, supra note 191; Milhaupt \& West, supra note 3, at 22; Puchniak, supra note 4, at 227.

193. See Milhaupt, supra note 191. 
retirement. ${ }^{194}$ This norm of lifetime employment for core employees, which was reinforced formally in the decades following the war by Japanese employment law, resulted in an illiquid labor market for core employees in listed companies. ${ }^{195}$ The lack of an external labor market inextricably ties the economic fate of Japanese lifetime employee managers to the economic future of their companies - creating an important sense of group identity among core lifetime employees and loyalty to their companies. This sense of group identity, or corporate culture, is further strengthened by the deep-rooted personal relationships that result from the lengthy tenure of career employees, relatively equal pay, and promotion from within the company. The development of a strong corporate culture, which promotes the success of the company, is also reinforced by the emphasis in Japanese culture on commitment to the group. ${ }^{196}$

Most importantly in the context of hostile takeovers, the most skilled lifetime employees in listed companies are rewarded late in their careers by being "promoted" to the board of directors, while still preserving their group identity as lifetime employees. As a result, boards of listed companies are dominated by lifetime employees who have a clear cultural bias towards resisting hostile takeovers. ${ }^{197}$ This culture is shared by most shareholders as all of Japan's major shareholders (i.e., Japanese banks, insurance companies and listed corporations) are governed by lifetime employees, and even a large segment of individual Japanese shareholders are themselves lifetime employees. Moreover, the judges and government regulators are also lifetime employees and thus are well-attuned to this cultural norm in shaping the evolution of Japan's hostile takeovers regime. ${ }^{198}$ From this perspective, although the exact impact of culture is difficult to measure, it seems clear that Japan's lifetime employment system is the foundation for a cultural bias against hostile takeovers and the glue that binds together stable shareholders.

However, during the lost decade, there were numerous reports that Japan's unique corporate culture, which sought to preserve the lifetime employee

194. Zenichi Shishido, Japanese Corporate Governance: The Hidden Problems of Corporate Law and Their Solutions, 25 DEL. J. CORP. L. 189, 203 (2000); Puchniak, supra note 4, at 208-209.

195. Shishido, supra note 194, at 203-04; Puchniak, supra note 4, at 209.

196. Ronald J. Gilson \& Mark J. Roe, Lifetime Employment: Labor, Peace, and the Evolution of Japanese Corporate Governance, 99 ColuM. L. REV. 508, 527-31 (1999); John O. Haley, Career Employment, Corporate Governance and Japanese Exceptionalism 3-4, 6 (Wash. U. Sch. Law Fac. Working Papers Series, Paper No. 04-04-01, 2004); Puchniak, supra note 4, at 208-09, 226-27; ENTERPRISE LAW, supra note 174, at 14-15, 93.

197. Bruce E. Aronson, The Olympus Scandal and Corporate Governance Reform: Can Japan Find a Middle Ground Between the Board Monitoring Model and Management Model?, 30 UCLA PAC. BASIN L.J. 93, 115 (2012); ENTERPRISE LAW, supra note 174, at 14-15.

198. Haley, supra note 196, at 3-4, 9; Curtis J. Milhaupt, Bull-Dog Sauce for the Japanese Soul? Courts, Corporations and Communities: A Comment on Haley's View of Japanese Law, 8 WASH. U. GLOBAL STUD. L. REV 345, 359 (2009) (observing that the Tokyo High Court's decision in Bulldog Sauce is "an example par excellence of this judicial tendency to protect the intermediate community (here, the corporation and its employees) against threats posed by the pursuit of individual interests. ...”). 
company community ${ }^{199}$ over short-term profits, had significantly eroded. The widely publicized takeover attempts by Horie, and to a lesser extent Murakami, were cited as evidence that Japanese corporate culture was becoming tolerant towards, if not accepting of, hostile takeovers. ${ }^{200}$ Many experts suggested that maximizing shareholder profits had become the most important incentive for Japanese managers as it was "no longer considered acceptable" for management of stable shareholder companies to block hostile takeover bids "regardless of the financial consequences to their own shareholders." 201

However, it appears that Japan's corporate and shareholder culture is more resilient than many predicted. Within the limits of this Article, we offer three pieces of evidence that demonstrate this point. First, the support for incumbent management by stable shareholders has consistently defeated takeover bids over the last several decades - even many bids offering significant premiums. This has not changed in recent times. ${ }^{202}$ As noted by Gen Goto, the support for incumbent management even appears to extend beyond formal stable shareholders (i.e., those with a business relationship with the target company) to Japanese shareholders more generally, ${ }^{203}$ and perhaps even to foreign investors who have come to realize that it does not pay to be the proverbial "nail that sticks up" in Japan's lifetime employee-dominated corporate culture. ${ }^{204}$

Second, even at the height of the wave of hostile takeover bids in 2006, an often cited survey of Japanese management reported that 77 percent of Japanese executives said that they would not even consider attempting a hostile takeover. ${ }^{205}$ Since then, Japan's perception of hostile takeovers has only worsened as the prosecution and humiliation of Japan's two most prominent corporate raiders has had a chilling effect on the market and hostile takeover attempts have virtually evaporated. ${ }^{206}$

Third, despite more than two "lost decades" of tepid economic performance, Japan’s lifetime employment system for core employees and lifetime employee

199. Shishido, supra note 194, at 203-204.

200. Milhaupt, supra note 4, at 2192; Puchniak, supra note 4, at 228.

201. Milhaupt, supra note 4, at 2186; Puchniak, supra note 4, at 228.

202. For example, Murakami's attempted hostile takeover of Shoei Corporation through his takeover boutique, M\&A Consulting in 2000. Despite offering a 40 percent premium over the 1999 market price, Murakami's bid failed miserably, accumulating only 6.5 percent of Shoei's shares, as stable and friendly shareholders gave their unconditional support to existing management and refused to tender their shares to Murakami. See Puchniak, supra note 4, at 242-43. Steel Partners' attempted hostile takeover of Bulldog Sauce also failed due to support from stable shareholders, who overwhelmingly approved the defensive measures proposed by existing management. See Oda, supra note 100, at 325.

203. Goto, supra note 7, at 142-43.

204. BuCHANAN ET AL., supra note 7, at 213-24; Maddison Marriage, Foreign Investors Fear Holding Japan Inc to Account, FIN. TIMES (Jan. 9, 2016), https://www.ft.com/content/080fd530-a7fe11e5-9700-2b669a5aeb83; Puchniak, supra note 4, at 245-50.

205. Top Execs Split on Approval for Oji's Run at Hokuetsu, NikKeI WKLy., Sep. 11, 2006; Puchniak, supra note 4, at 250.

206. Puchniak, supra note 4, at 260. 
dominated boards have been largely maintained. ${ }^{207}$ This is surprising considering repeated predictions that Japan's lifetime employee system would disappear ${ }^{208}$ and several legislative efforts to make boards of Japanese companies more independent. ${ }^{209}$

It is noteworthy that corporate culture in Japan can change quickly. We should not forget that lifetime employment is a post-war phenomenon and that Japan in fact had a liquid labor market before World War II. ${ }^{210}$ As such, we are not suggesting that because Japan's corporate culture has been a major hurdle to hostile takeovers in the past that it will not change in the future. However, it does seem that Japan's unique lifetime employee-centered corporate culture has been an important force which has caused the Japanese market for hostile takeovers to evolve differently than those markets in the United States or United Kingdom. Although it is difficult to precisely measure the impact of Japanese corporate culture on the market for corporate control, it seems clear that it has played a role in stifling the development of hostile takeovers in Japan. Japan's unique corporate culture provides a strong rationale for the durability of stable shareholding and the seemingly irrational behavior of "friendly" shareholders who have no business connection to a target company, but nevertheless support management to fend off a hostile takeover attempt. Moreover, it provides an explanation for the general trend among government regulators and judges to support lifetime employee dominated boards in defeating hostile bids. ${ }^{211}$

\section{PART VI: AVOIDING HISTORY FROM REPEATING ITSELF}

In light of the history of incorrect predictions about the development of a vibrant market for hostile takeovers in Japan, we conclude with an important caveat: this Article makes no prediction about the future of hostile takeovers in Japan. Rather, it claims that Japan is an interesting example of an important jurisdiction, which for over two decades had a dispersed shareholding landscape,

207. Although the lifetime employment system has experienced some degree of erosion, it has generally been maintained for "core” Japanese employees. See ENTERPRISE LAW, supra note 174, at 93; Sayuri A. Shimoda, Time to Retire: Is Lifetime Employment in Japan Still Viable?, 39 FORDHAM INT’L L.J. 753, 773-74 (2016).

208. Shimoda, supra note 207, at 771-73 (citing multiple quantitative studies observing and predicting the decline of lifetime employment in Japan); JAPAN INST. FOR LAB. POL'Y \& TRAINING, LABOR SITUATION IN JAPAN AND ITS ANALYSIS: GENERAL OVERVIEW 2015-2016 (2016), http://www.jil.go.jp/english/lsj/general/2015-2016/3-1.pdf.

209. Gen Goto et al., Japan's Gradual Reception of Independent Directors: An Empirical and Political-Economic Analysis, in INDEPENDENT DiRECTORS IN ASIA: A HISTORICAL, CONTEXTUAL AND COMPARATIVE APPROACH 135 (Dan W. Puchniak et al. eds., 2017) (explaining the legislative history and development of independent directors in Japan).

210. Gilson \& Roe, supra note 196, at 518-20.

211. The Japanese government has taken various steps to promote the use of poison pills. In 2001, the Commercial Code was amended to permit use of poison pills. The Ministry of Economy, Trade and Industry and the Ministry of Justice "officially sanctioned” the use of poison pills in 2005, following uncertainty about the 2001 amendments. In 2006, the Companies Act increased the varieties of poison pills available. See Puchniak, supra note 4, at 223-24. 
undervalued companies, and a hostile takeovers regime that was ostensibly inspired by the United Kingdom and United States, but yet did not develop a vibrant market for hostile takeovers.

One way of interpreting this claim is that the three general criteria for predicting whether a hostile takeovers regime will develop (i.e., dispersed stock ownership, depressed share values, and a United Kingdom-United States inspired regulatory framework) are too loosely defined and limited in their scope to have much predictive value. The case of Japan highlights the fact that empirically dispersed shareholders come in different varieties, and that these varieties can have a distinct impact on the evolution of a jurisdiction's market for corporate control. In addition, the influence of Japanese corporate culture on the evolution of hostile takeovers in Japan is a poignant reminder of how unique factors may arise in different jurisdictions that cause hostile takeovers (and, we suspect almost all corporate governance mechanisms) to evolve in unanticipated jurisdiction-specific ways. ${ }^{212}$

Another way of interpreting our claim is that a proper understanding of Japan demonstrates that in reality it had neither a stereotypically dispersed shareholding environment nor a regulatory system closely (or even loosely) modelled on the United Kingdom or United States regulatory regimes. From this perspective, perhaps Japan does not debunk the general theory that a jurisdiction with stereotypical Berle-Means-type dispersed shareholding, undervalued companies and a United Kingdom or United States inspired regulatory system will inevitably develop a vibrant market for hostile takeovers. We can accept this interpretation from a purely theoretical perspective, but suggest that it is of little practical use.

As illustrated in this Article, it is likely that most (if not all) jurisdictions, including the United States and United Kingdom, have varieties of shareholders that do not neatly conform to the blunt dispersed versus concentrated dichotomy. In this sense, this general theory does not even accurately describe the United Kingdom or United States - the jurisdictions from which it was purportedly derived. Further, although it is inaccurate to claim that Japan's pre-2005 law closely, or even loosely, took up the core features of the United Kingdom's City Code or that Japan's post-2005 law closely, or even loosely, resembles Delaware law, we suspect that this is true of most systems. The fact is that most regulatory systems end up with their own unique and important aspects and, in this respect, Japan is not unique. In the end, this Article reminds us that in order to understand hostile takeovers in any given jurisdiction, it is best to understand that jurisdiction on its own terms.

\footnotetext{
${ }^{212}$ For other examples of such developments with other corporate governance mechanisms in the context of Asian and Japanese corporate law and governance, see Puchniak \& Kim, supra note 15; Puchniak, supra note 15.
} 